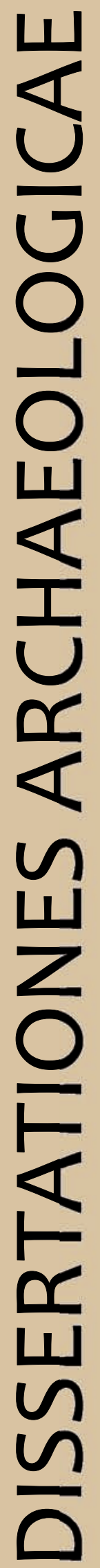

ex Instituto Archaeologico Universitatis de Rolando Eötvös nominatae

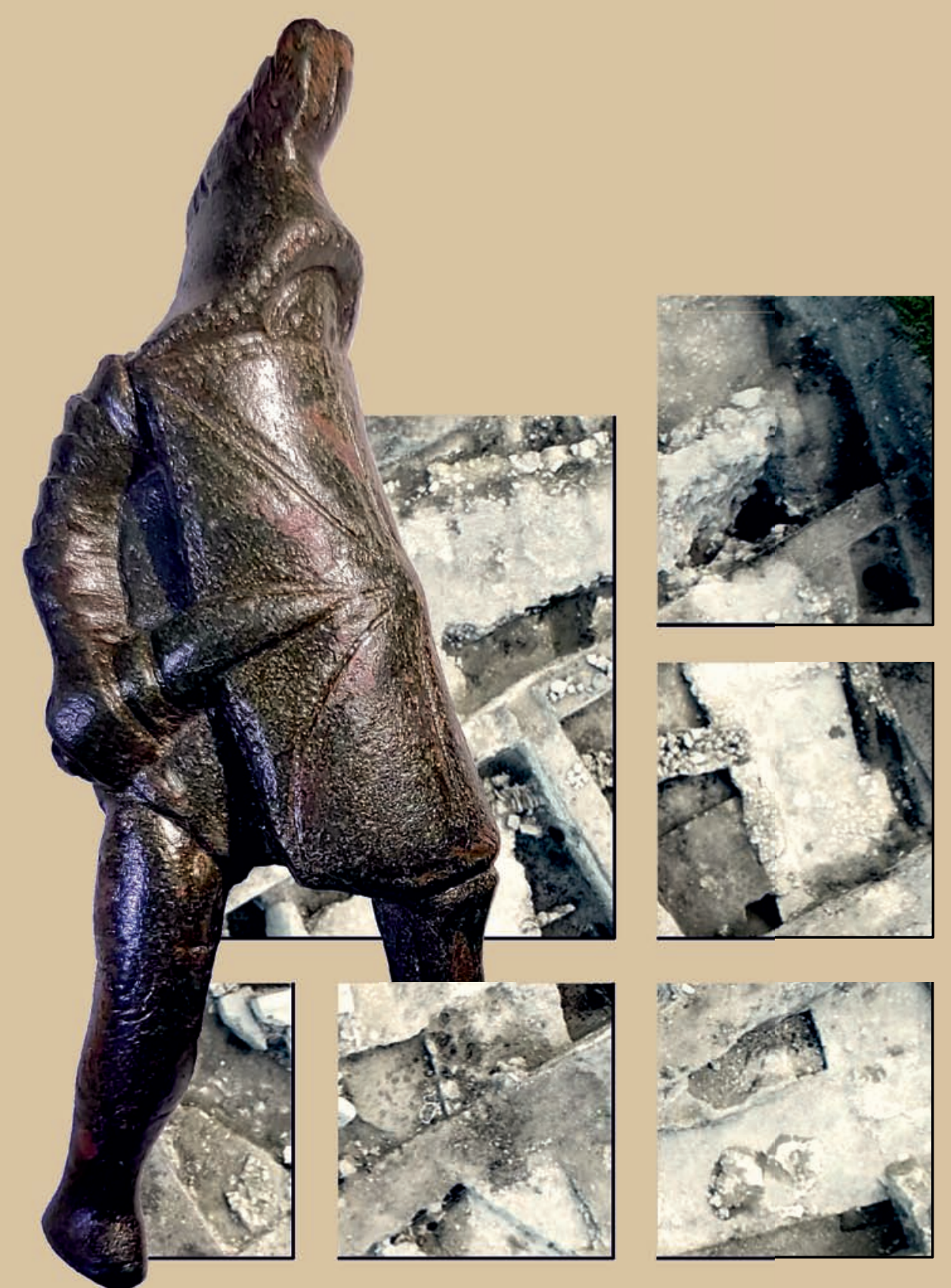

$$
\text { Ser. 3. No. 7. } 2019
$$




\section{Dissertationes Archaeologicae ex Instituto Archaeologico}

Universitatis de Rolando Eötvös nominatae Ser. 3. No. 7.

Budapest 2019 
Dissertationes Archaeologicae ex Instituto Archaeologico Universitatis de Rolando Eötvös nominatae

Ser. 3. No. 7.

Editor-in-chief:

DÁvid BARTUS

Editorial board:

LÁsZló BARTOSIEWICZ

LÁSZLÓ BORHY

ZOLTÁN CZAJLIK

IsTVÁN FELD

GÁBOR KALLA

PÁL RACZKY

MikLÓs SzABÓ

TivadAR VidA

Technical editor:

GÁBOR VÁCZI

Proofreading:

SZILVIA BARTUS-SZÖLLősI

ZsóFIA KondÉ

Aviable online at http://dissarch.elte.hu

Contact: dissarch@btk.elte.hu

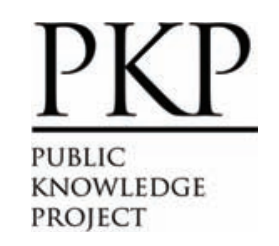

๑ ELTE Eötvös Loránd University, Institute of Archaeological Sciences

Layout and cover design: Gábor Váczi

Budapest 2019 


\section{CONTENTs}

\section{ARticles}

János Gábor TARBAY

The Casting Mould and the Wetland Find - New Data on the Late Bronze Age

Peschiera Daggers

Máté MeRvel

Late Bronze Age stamp-seals with negative impressions of seeds from Eastern Hungary

János Gábor TARBAY

Melted Swords and Broken Metal Vessels - A Late Bronze Age Assemblage

from Tatabánya-Bánhida and the Selection of Melted Bronzes

Ágnes ScHNEIDER

Multivariate Statistical Analysis of Archaeological Contexts: the case study

of the Early La Tène Cemetery of Szentlörinc, Hungary

Csilla SÁRÓ - Gábor LASSÁNYI

Bow-tie shaped fibulae from the cemetery of Budapest/Aquincum-Graphisoft Park

Dávid BARTus

Roman bronze gladiators - A new figurine of a murmillo from Brigetio

Kata DÉvAI

Re-Used Glass Fragments from Intercisa

Bence Simon

Rural Society, Agriculture and Settlement Territory in the Roman, Medieval and Modern Period Pilis Landscape

Rita RAKONCZAY

„Habaner“ Ofenkacheln auf der Burg Čabrad”

\section{FIELD REPORT}

Bence Simon - Anita Benes - Szilvia Joháczi - Ferenc BARnA

New excavation of the Roman Age settlement at Budapest dist. XVII, Péceli út (15127) site 


\section{Thesis Abstracts}

Kata SzILÁGYi

Die Silexproduktion im Kontext der Südosttransdanubischen Gruppe

der spätneolithischen Lengyel-Kultur

Norbert FARAGÓ

Complex, household-based analysis of the stone tools of Polgár-Csőszhalom

János Gábor TARBAY

Type Gyermely Hoards and Their Dating - A Supplemented Thesis Abstract

Zoltán Havas

The brick architecture of the governor's palace in Aquincum

Szabina Merva

'...circa Danubium...' from the Late Avar Age until the Early Árpádian Age-

$8^{\text {th }}-11^{\text {th }}$-Century Settlements in the Region of the Central Part of the Hungarian

Little Plain and the Danube Bend

Szabolcs Balázs NAGY

Noble Residences in the $15^{\text {th }}$ century Hungarian Kingdom - The Castles of Várpalota,

Ujlak and Kisnána in the Light of Architectural Prestige Representation

Ágnes KollátH

Tipology and Chronology of the early modern pottery in Buda 


\title{
Bow-tie shaped fibulae from the cemetery of Budapest/Aquincum-Graphisoft Park
}

\author{
CSILla SÁRÓ \\ MTA-ELTE Research Group \\ for Interdisciplinary Archaeology \\ sarocsilla@gmail.com
}

GÁBOR LASSÁNYI

Castle Headquarters Integrated Regional

Development Centre Nonprofit Ltd

lassanyi.g@gmail.com

\begin{abstract}
The main aim of this paper is the presentation of two rare fibulae from the Eastern Cemetery of the civil town of Budapest/Aquincum. On the former territory of the Óbuda Gas Factory, new parts of the cemetery were excavated during the years 2004-2017 under the direction of G. Lassányi. The fibulae discussed in our study were found in the skeleton grave No. 795. These fibulae have a special form and their type can be defined easily. They belong to a low-numbered fibula type of Pannonia, the bow-tie shaped fibulae.
\end{abstract}

\section{The Eastern Cemetery of the civil town of Aquincum (Graphisoft Park)}

The systematic archaeological exploration of the Eastern Cemetery of the civil town of Aquincum started in 1998 connected to the development project 'Graphisoft Park' in the area of the former Óbuda Gas Factory. ${ }^{1}$ Although several burials of the so called 'Gas Factory Cemetery' were documented in the last one and a half century, ${ }^{2}$ the real size and importance of this necropolis was demonstrated in the first years of the new Millennium.

Field works in this area continued in several phases in the last two decades in parallel with the development projects, and the largest archaeological excavations took place between 2005 and 2007. During this period more than 1500 Roman period burials were documented.

According to current data this cemetery was opened at the end of the $1^{\text {st }}$ century AD on the sandy dunes on the bank of the Danube East from the town, and was continuously in use until the end of the $3^{\text {rd }}$ century $\mathrm{AD} /$ beginning of the $4^{\text {th }}$ century $\mathrm{AD}$, which produced a large number of superpositions in the central area of the necropolis.

Roughly half of the graves were scattered ashes cremation burials, urn burials were extremely rare. A large number of plain inhumation and coffin burials were also discovered, in some cases the bones' position indicated that the body was wrapped in textiles, and a few number of stone casket and brick-built burials were also excavated. During rescue excavations in the $19^{\text {th }}$ and first half of the $20^{\text {th }}$ centuries a few sarcophagi were also discovered in this area. ${ }^{3}$

In the first years of the $20^{\text {th }}$ century, northeast from the central area of the cemetery a group of Late Roman Age (late $4^{\text {th }}$ century AD) burials containing more than a hundred inhumation graves were documented around a possible Early Christian grave chapel. A few graves of this

\footnotetext{
ZsIDI 1999; BUGÁN 2000; ZsIDI - REMÉNYI 2003.

KuZSINSZKY 1892; ZsIDI 1997; ZsIDI 2001.

KuZSINSZKY 1892, 446; LASSÁNYi 2007, 111-112; LASSÁNYi 2017, 78.
} 
late period were also found scattered in the $1^{\text {st }}-3^{\text {rd }}$ century $\mathrm{AD}$ cemetery area, one of these burials containing an antler comb dated to the late $4^{\text {th }}$-early $5^{\text {th }}$ century $\mathrm{AD} .^{4}$

South from the central area several grave groups of $2^{\text {nd }}$-late $3^{\text {rd }} /$ early $4^{\text {th }}$ century AD burials were excavated between 2010 and 2019 (Graphisoft South Cemetery). ${ }^{5}$

Large industrial earth works of the last 150 years mostly destroyed all remains of grave monuments near the surface, stone stele bases and foundations of stone built burial monuments could be documented sporadically. ${ }^{6}$

A large amount of grave goods, ceramic and glass vessels and small metal finds were documented in the graves. Altogether 19 graves contained fibulae or fragments of fibulae (Graves No. 251, 255, 381, 429, 435, 453, 483, 496, 558, 590, 615, 664, 784, 795, 1036, 1069, 1319, 1341, 1342). These were scattered ashes cremation burials (Graves No. 251, 255, 381, 435, 453, 615, 784, 1342.), plain inhumation burials (Graves No. 429, 483, 496, 558, 795, 1036), coffin burials (Graves No. 590, 664, 1069, 1341) and a brick built burial with a possible wooden coffin (Graves No. 1319). Another seven fibulae without grave context were discovered in the area of the cemetery. ${ }^{7}$

\section{The current study presents the pair of fibulae discovered in Grave No. 795.}

\section{Grave No. 795 (Fig. 1)}

Grave No. 795 was found during the excavation period of 2006. It is a partly disturbed double grave and was intersected by grave No. 788 which is the inhumation burial of a woman. ${ }^{8}$ Grave No. 795 has a rectangle pit with an uncertain outline. The grave contained the extended body of a woman aged 25-29 years and a child aged 3-4 years in a northeastsouthwest orientation. The woman's head was possibly supported; she hugs the child with her right arm, while her left arm is stretched next to the body. Her right hand possibly held the child's left. Only two fibulae were found on the woman's shoulders and no other grave goods were documented. ${ }^{9}$

4 LASSÁNYI - VASS 2015.

5 LASSÁNYI 2010, 28; LASSÁNYi 2011, 48-49; LASSÁNYi 2016, 147-148; LASSÁNYi - SZEREDi 2017, 86-87. Further studies about the finds in the area: LASSÁNyi 2005; GABLER - HÁrSHEGyi - LASSÁNyi 2009; VÁMOS LASSÁNYI 2010.

6 LASSÁNyi 2006; LASSÁNyi 2007; LASSÁNYi 2008; LASSÁNyi 2017, 78.

7 Detailed study: Sáró, Cs.: Roman age fibulae from the Eastern Cemetery of the civil town of Aquincum (Graphisoft Park). Unpublished yet.

8 Burial rite: inhumation burial. Deceased: woman aged 20-29 years. Grave-goods: Dress accessories: one bracelet of jet beads, one silver finger-ring, one gold earring. Coin: one as, Severan dynasty (front: the head of a young boy turns right, back: PRINCIPI IVVENTVTIS). Further objects: one iron knife with a handle made of ebony, one big iron nail, a fragment of a marine shell. Glass objects: one uncolored one-handled glass jug with a gold plaque on its handle, two small unguent bottles. Pottery: one African Red Slip Ware, an El-Aouja jug (LASSÁNYI - VÁmOs 2011), pottery fragments. The El-Aouja jug was dated back to 200-280 AD (LASSÁNYi - VÁmos 2011, 156, 158). The grave No. 788 dates back to the last decades of the $3^{\text {rd }}$-first decades of the $4^{\text {th }}$ centuries (LASSÁNYI - VÁmos 2011, 160).

9 We presented the information according to the excavation documentation. The data on the anthropological remains were provided by Zsolt Bernert (Museum of Natural History). 
$R^{N}$

Fibula 1

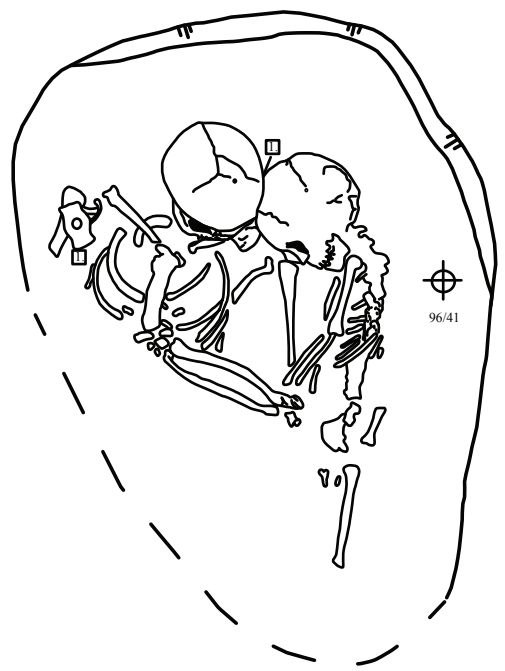

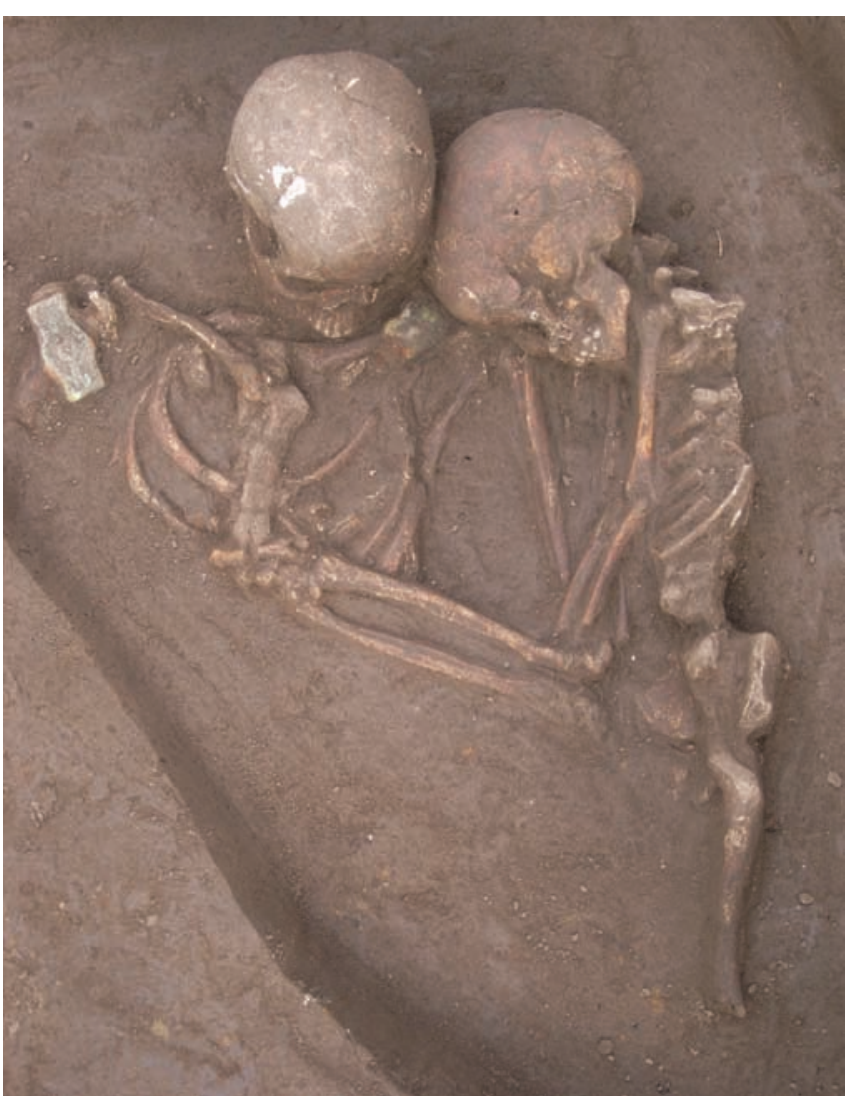
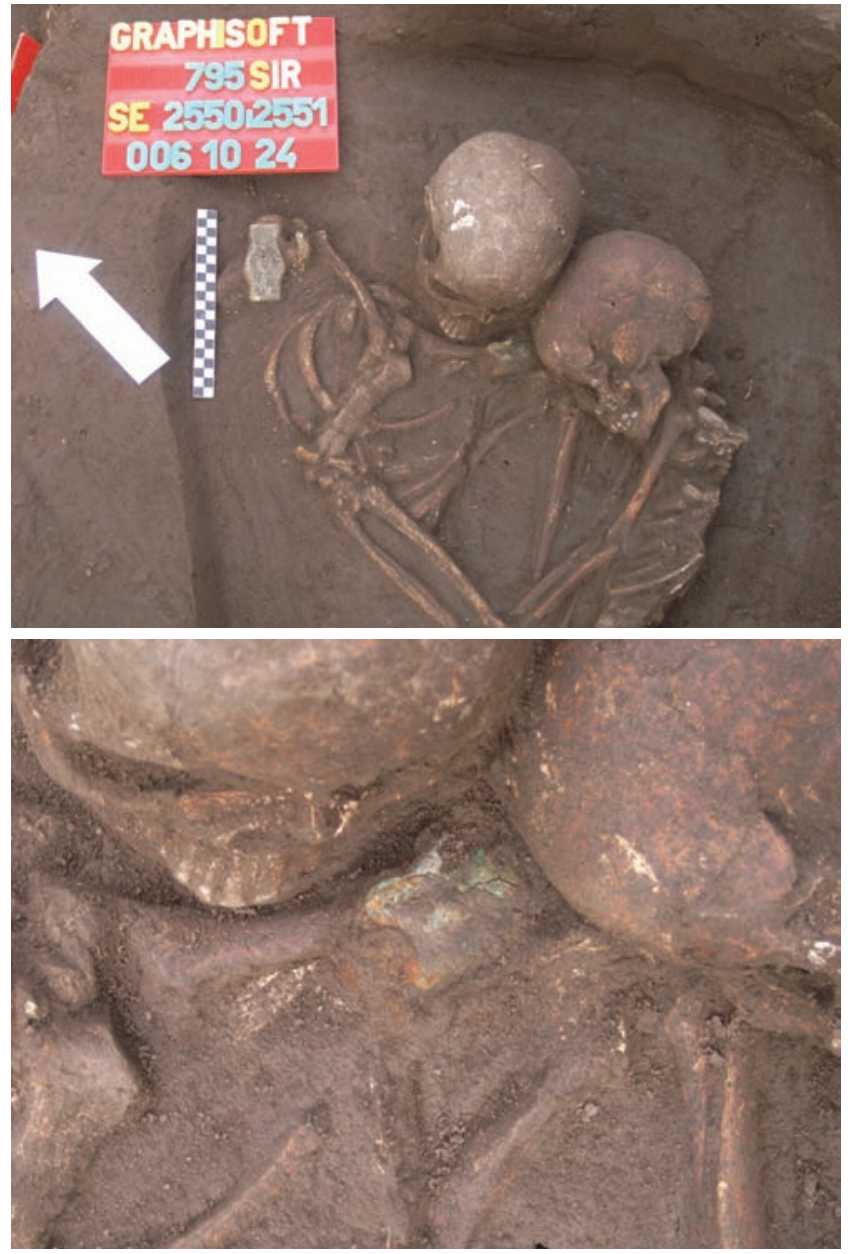

Fig. 1. The grave No. 795 . 


\section{Fibulae from grave No. 795}

Based on scientific literature, the type of the fibulae can be easily defined. They belong to a rare Pannonian type which is named bow-tie shaped fibula. ${ }^{10}$ Exampless of this type belong to plate fibulae. They were made of two pieces, namely the bow and the pin-construction, which were made separately and these parts were attached by an axis bar. Bow-tie shaped fibulae were made of copper-base alloy and iron. The basic data of the two bow-tie shaped fibulae are as follows:

No. 1 (Fig. 2.1)

Inv.no.: $\mathrm{AM}^{11}$ 2006.5.4739.1.

Size: Length ${ }_{\text {bow }}: 7.8 \mathrm{~cm}$, Width $_{\text {bow }}: 3.9 \mathrm{~cm}$, Thickness bow $: 0.7-0.5 \mathrm{~cm}$

Description: The fibula is broken. The two-piece fibula is made of iron and copper-base alloy. Pin-construction: made of iron, consistsing of $3+3$ wires with internal chord and an axis bar. Bow: made of iron and has a sheet-cover made of copper-base alloy, the sides of the bow are double arched, the metal sheet is decorated with embossing technique. Catchplate: made of iron and it is broken.

No. 2 (Fig. 2.2)

Inv.no.: AM 2006.5.4740.1.

Size: Lengthbow: $7.9 \mathrm{~cm}$, Widthbow: $3.9 \mathrm{~cm}$, Thicknessbow: $0.9-0.5 \mathrm{~cm}$

Description: The fibula is broken. The two-piece fibula is made of iron and copper-base alloy. Pin-construction: made of iron, it consists of $3+3$ wires with internal chord and an axis bar. Bow: made of iron and has a sheet-cover made of copper-base alloy, the sides of the bow are double arched, the metal sheet is decorated with embossing technique. Catchplate: made of iron, it is small and broken.

The two fibulae were investigated by the stereomicroscope ${ }^{12}$ in Archaeometry Laboratory of the Eötvös Loránd University, Faculty of Humanities, Institute of Archaeological Sciences. ${ }^{13}$ Our investigations focused on the motives and the decoration process of these fibulae. In the following, we would like to present our observations.

First, the the observations on the motives will be discussed. Three main ornaments and some other additional motives can be seen on both fibulae. There is a cicada above the pin-construction, a standing female figure above the catchplate and an umbo in the center of each surface (Fig. 3.1-2). In these parts the interior iron element of each bow is raised and the copper-base alloy sheet is embossed.

The standing woman wears a garment which can be examined according to the tombstones with depicted women in native dress. ${ }^{14}$ The following statements can be made about the elements of the dress: 1 . Both women wear hats without veils or other ornaments. 2 . Their

10 Variations of the name: bow-tie shaped brooch (TopÁL 1981a, 93), "bow-tie”-shaped sheet metal fibula (F. PETres 1990, 13), csokor alakú fibula (F. Petres 1965, 90; Fitz 1957, 141; ErdÉLYi 1974, 32), csokorfibula (K. PALÁGYi NAGY 2000, 140), "kettősen ívelt, pajzs alakú fibula” (ERDÉLyi - FüLEP 1954, 254, Nr. 172), lemezfibula (csokorfibula) (B. Bónis 1975, 248), Maschenfibel (Bínó 2003, 92), mask or plate brooch (Rothe 2012, 214), pajzs alakú fibula (NAGy 2007, 57, Nr. 49), pannonian plated fibula (Csontos 1999, 157), Plattenfibel (NAGy 2001, 140), schildförmig Fibel (GARBSch 1965, 161, Nr. 154.2), szalagcsokor alakú fibula (ERdÉLYi - FüleP 1954, 254, Nr. 173; ERdÉLYi 1974, 97-98), “téglalap alakú, kettősen ivelt szélü fibula”(ERDÉLYi - FüleP 1954, 242, Nr. 61).

11 Aquincumi Múzeum és Régészeti Park/Aquincum Museum and Archaeological Park, Budapest.

12 We used the ZEISS SteREO Discovery.V8: zoom (zoom range 6.3×-80×) stereomicroscope of the Archaeometry Laboratory. The microscope was purchased within the KMOP-4.2.1/B-10-2011-0002 tender: Interdisciplinary and innovative research directions and development of background for industrial co-operation and introduction of teaching new educational technologies at ELTE Eötvös Loránd University.

13 We would like to express our gratitudes to Zsuzsanna Tóth, research fellow of the ELTE Eötvös Loránd University Faculty of Humanities, Institute of Archaeological Sciences, for her help during the investigation.

14 On the subject, one of the most important studies is the monographic study of J. Garbsch (GARBSCH 1965). See more recently: Rothe 2012; RoTHE 2013; SÁRó 2018. 

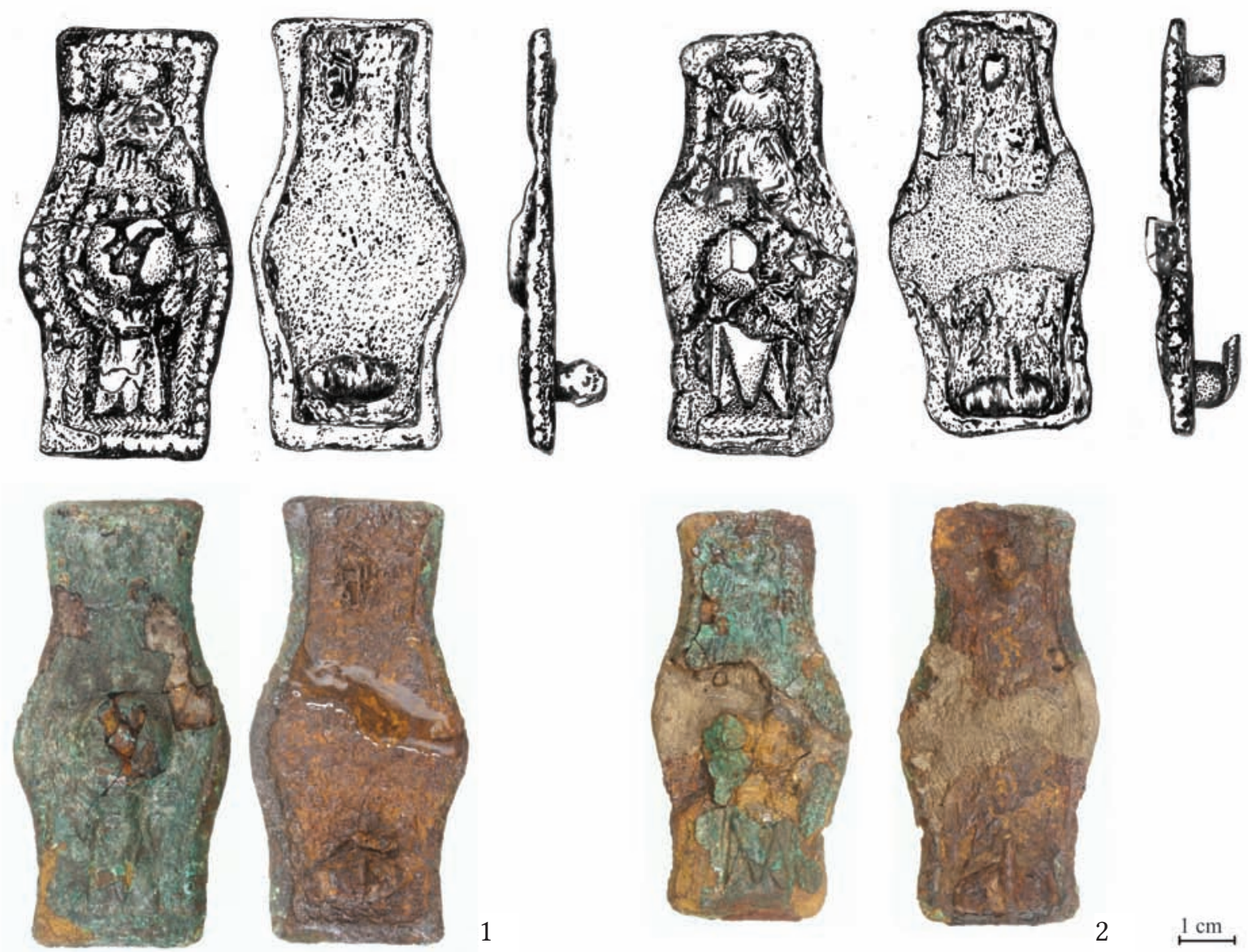

Fig. 2. 1 - Bow-tie shaped fibula Nr. 1,2 - Bow-tie shaped fibula Nr. 2.
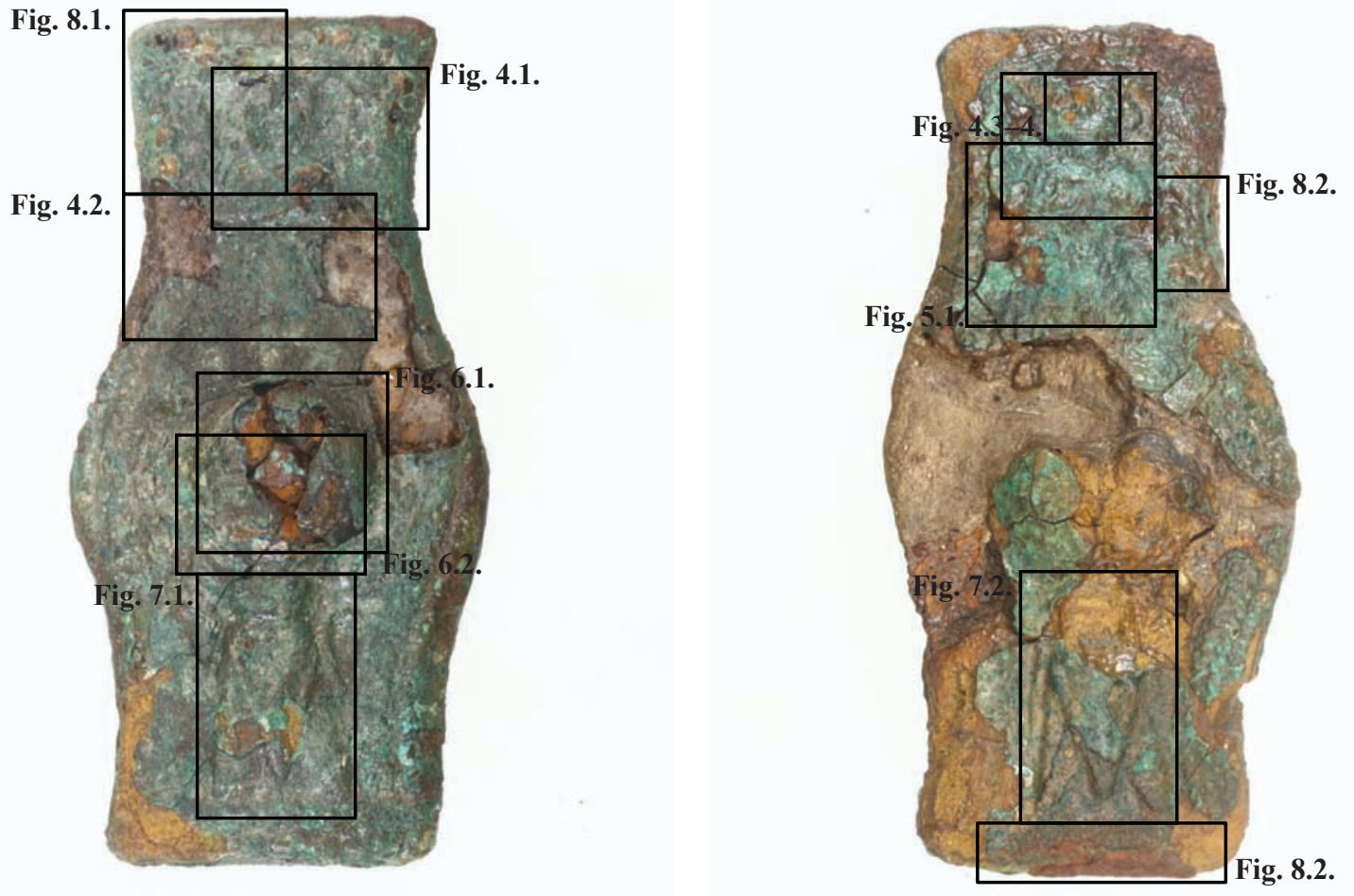

Fig. 3. Summary of the details. 1 - fibula Nr. 1,2 -fibula Nr. 2. 
undergarment has a round neckline. 3. The upper part of the overgarment is plaited but no details of a fibula can be noticed. 4. Some kind of belt can be observed according to the deep line between the upper part and the skirt. 5. The skirt of the overgarment is also plaited. The folds of the skirt may have a "V" shape on the fibula No. 2. 6. Neither aprons nor shoes were depicted on the fibulae (Fig. 4).

Despite the small size, the women's bodies were elaborated in detail. Firstly, we would like to describe the faces. On fibula No. 1 the round chin, the mouth and the nose can be seen well, while the eyes can only be guessed at (Fig. 4.1). The face of the woman is even more recognizable on fibula No. 2. Her face is triangular and pointed towards the chin which has a round shape. Her mouth is detailed because a thin line divides the lips. The woman has a full upper lip and a smaller underlip. Her drop-shaped nose is close to the eyes which have a simple round shape without a pupil (Fig. 4. 3-4).

The pose of the women on the fibulae also appears on the pictures of tombstones. The woman on fibula No. 1 lifts her right arm in front of her. Unfortunately we cannot see if she has something in her hand. On fibula No. 2 the woman's figure is clearly visible. She lifts each of her arms in front of her at the waist and she bends her arms from the elbows. Both her palms are turned upwards. From Pannonian tombstones we know this position well, depicting women with fruit or some other object in their hands (Fig. 5.1). ${ }^{15}$

The umbo is placed in the center of each fibula. This motif is raised on the interior iron element just as the women's figures. On fibula No. 1 the surface of the umbo is plain and it has a convex shape. A pair of simple ribs can be seen on the edge of the raised surface, while a braided edge-ornament can be observed at the base of the umbo (Fig. 6). The umbo of fibula No. 2 is in a poor condition. In spite of this, its form seems simpler than the umbo mentioned before. There is no trace of ribs on the top of this umbo and we can only guess at a braided edge-ornament at the base.

Both of the cicadas are embossed on each surface. The cicada of fibula No. 1 is well preserved. The head of the cicada looks toward the umbo and it is bug-eyed. A rib separates the head and the thorax and the wings are pointed and triangular. A small fragment of the braided edge-ornament can be observed under the wings (Fig. 7.1). Unfortunately the cicada on fibula No. 2 is as fragmental as the umbo. Although the metal sheet on the head was not preserved, it is still present on the thorax, the abdomen and the wings. The abdomen is shorter than the wings but it also has a pointed end. On the left wing a longitudinal rib can be seen (Fig. 7.2). Though the shape of the bug is fragmentary, its scale is similar to the cicada on fibula No. 1. A difference of the two designs is still noticeable. On fibula No. 2 the cicada and the umbo are too close to each other, the head of the cicada can barely fit under the umbo. Looking at the scale of the fibula, the umbo does not seem to be in the middle, it slips towards the cicada.

15 Examples: The woman in native dress holds a round object or fruit in her right hand: Lupa 707, 740, 830 and 2838. The woman in native dress holds a round object or fruit in her left hand: Lupa 3175 . The woman in native dress holds a rectangle object in her right hand: Lupa 2583, 3061 and 5984. The woman in native dress holds a round object or fruit in her left hand: Lupa 5989. The woman in native dress maybe holds a handkerchief in her right hand: Lupa 3273 and 9842 . The woman in native dress holds a round object or fruit in her right hand and a fruit in her left hand: Lupa 735. The woman in native dress holds a fruit in her hands. Her right palm turns down and her left palm turns up: Lupa 765, 774, 2973, 3052 and 5042. Both women in native dress hold a fruit or a bowl in her hands. Her right palm turns down and her left palm turns up: Lupa 5666. 

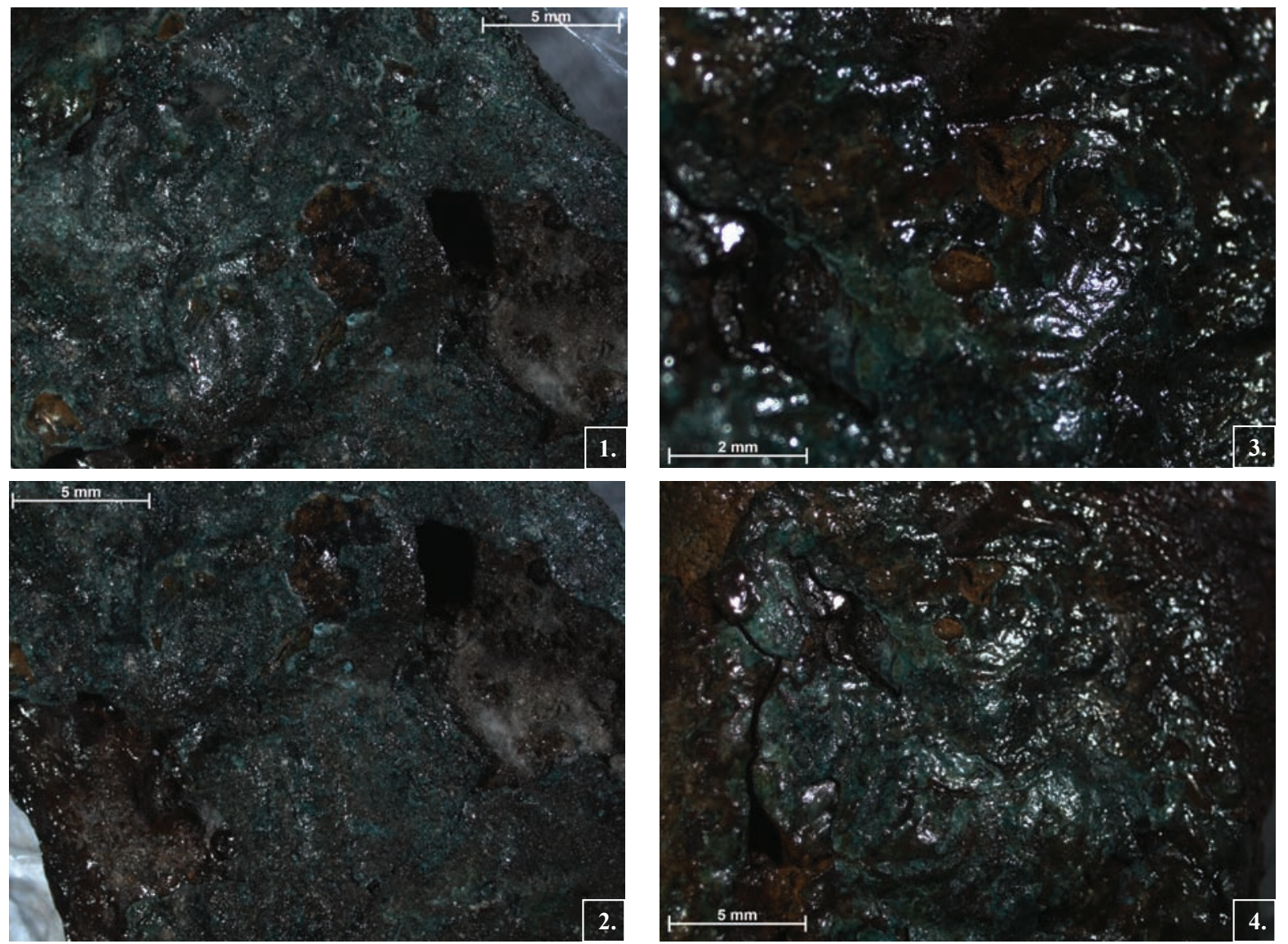

Fig. 4. 1-2 - The woman on the fibula Nr. 1. Fig. 4, 3-4 - The woman on the fibula Nr. 2.

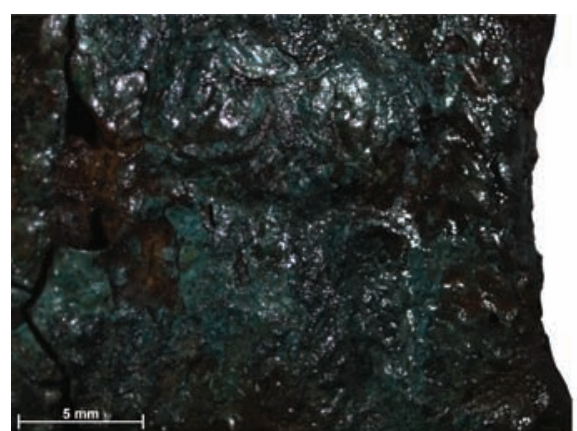

1

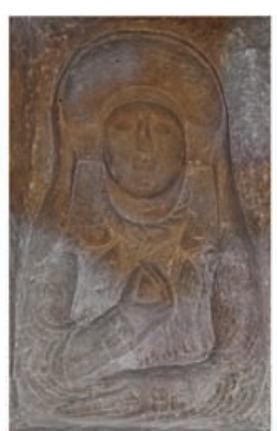

2.1

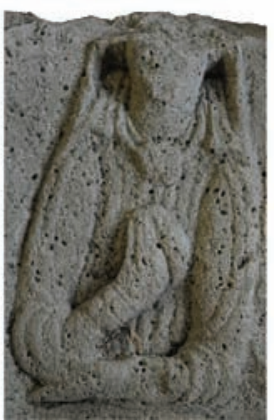

2.4
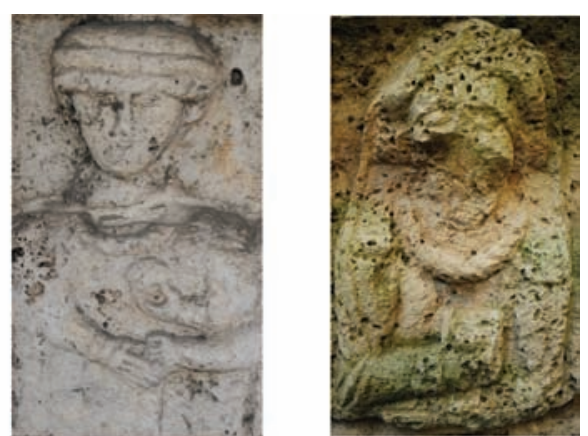

2.2

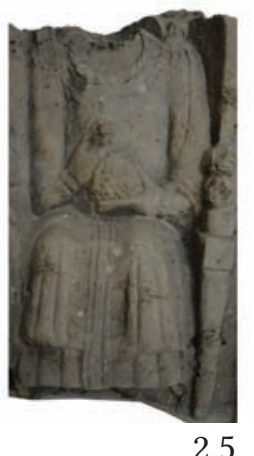

Fig. 5. 1 - Position of the hands on the fibula Nr. 2, 2 - Position of the hands on tombstones: 1 - Szentendre, Lupa 740, 2 - Szentendre, Lupa 3175, 3 - Esztergom, Lupa 5984, 4 - Szomor, Lupa 3273, 5 - Iszkaszentgyörgy, Lupa 735, 6 - Budapest, Lupa 765. All photos were made by Cs. Sáró. 
An edge-ornament can be seen on both fibulae. A braided edge-ornament can be well observed on fibula No. 1 and beside another edge-ornament of semi-globes can be seen on some parts (Fig. 8.1). The braided edge-ornament on fibula No. 2 is well identifiable (Fig. 8.2) but the other edge-ornament cannot be convincingly identified. The braided edge-ornament next to the woman's body is close to the edge of the fibula edge which means another edge-ornament cannot fit in there.

When looking at the decoration technique, the metal composition too is visible to the naked eye. These fibulae were made of iron and copper-base alloy so that the interior element is made of iron and it is covered with a copper-base alloy sheet. As we mentioned above, the main decorative elements such as cicadas, umbos, women and edge-ornaments have already been hewn on the interior iron element. If we examine the back of the fibulae we can see the narrow edge formed by bending the copper-base alloy sheet (Fig. 9). First the sheet was attached to the upper side of the fibula and then the rest was finished on the underside. The rest of the sheet was not only cut off but it was also bent to the back of the fibula. In the case of both fibulae, it seems to have been bent along the long sides first and then on the short sides.

On both fibulae, drop-shaped ornaments can be recognized next to the figures. On each side of the cicada on fibula No. 1 drop-shaped low fields can be noticed (Fig. 10.1-3). On fibula No. 2 the same ornaments can be seen not on each side of the cicada but the woman's figure (Fig. 10.4-6). It is important to emphasize that these fields are not embossed but deepened. Perhaps they were not just used to decorate and fill the surface but they have a functional role. When the copper-base alloy sheet was put on the interior iron element, several tools were used to attach and fix it. Maybe the dropshaped fields are the imprints of a tool used for this purpose.
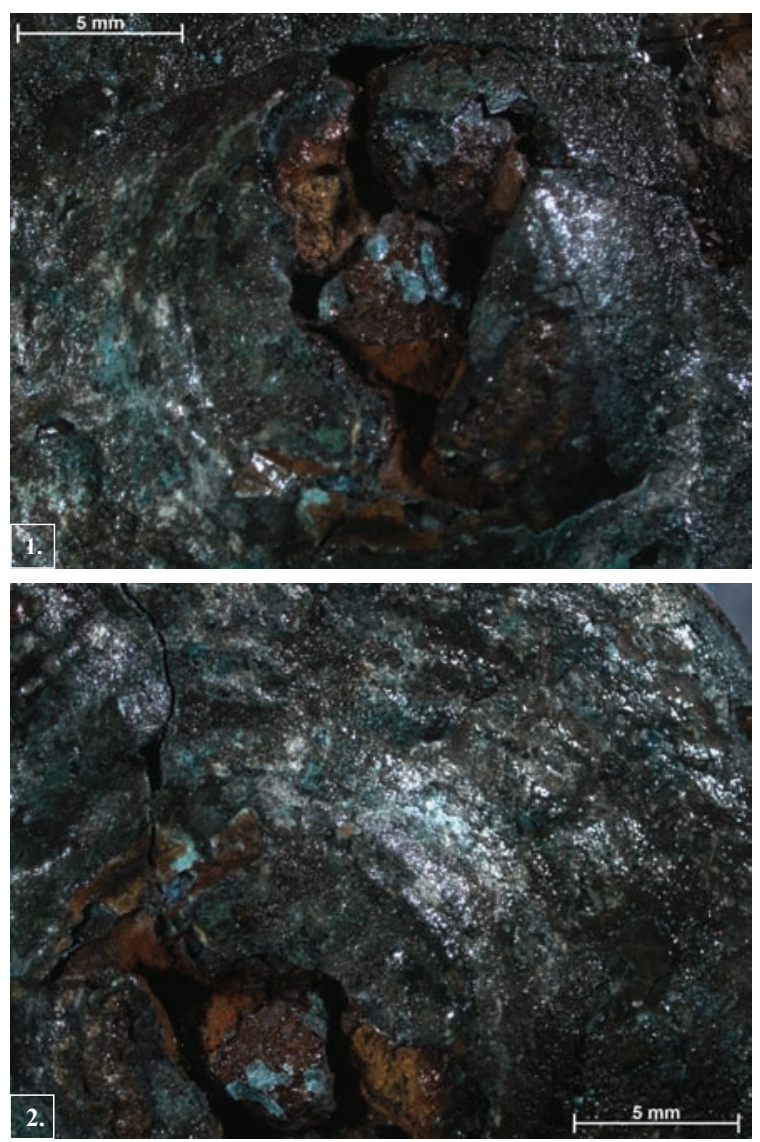

Fig. 6. The umbo on the fibula Nr. 1.
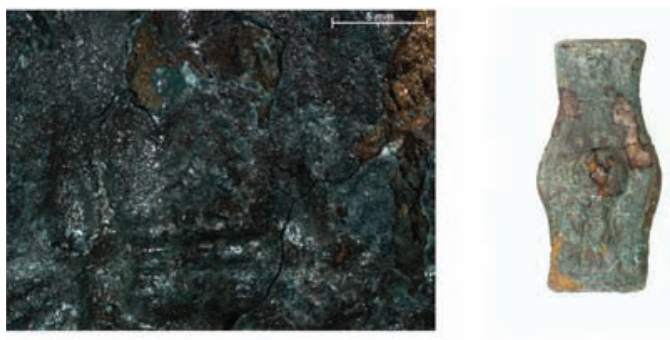

1
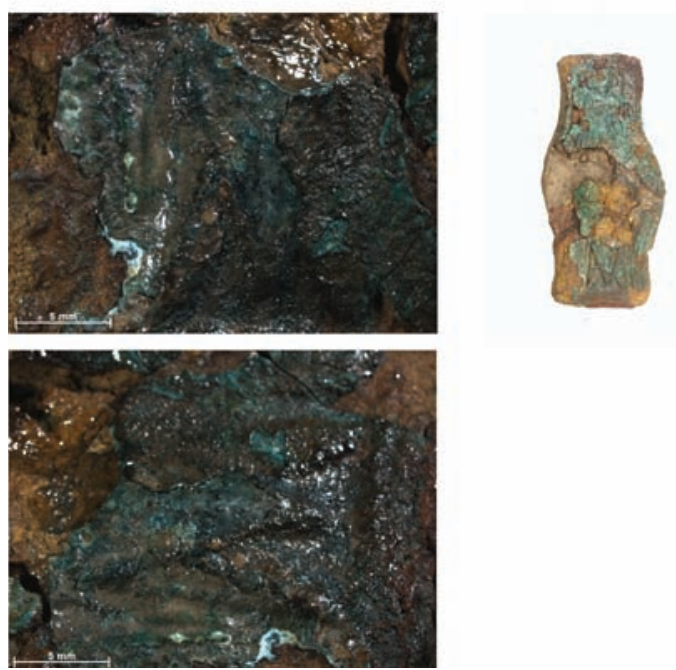

Fig. 7. The cicada motif on fibulae: $1-$ Nr. 1 , $2-$ Nr. 2. 


\section{Bow-tie shaped fibulae from Pannonia}

Bow-tie shaped fibulae have not been mentioned in the monographic studies of Ilona Kovrig and Erzsébet Patek. ${ }^{16}$ At first, these fibulae were published in the 1950's and 1970's from the tumuli of Pátka, ${ }^{17}$ Pusztaszabolcs-Felsőcikola ${ }^{18}$ and the cemetery of Mány. ${ }^{19}$ In her summarizing study, Katalin Csontos discussed this type in detail. ${ }^{20}$

The number of formerly published fibulae can be supplemented with further pieces, but the number of similar pieces is still very low. Bow-tie shaped fibulae were found at: Adony/Vetus Salina (1 piece), ${ }^{21}$ Budapest/Aquincum (4 pieces), ${ }^{22}$ Dunakömlöd/Lussonium (1 piece) ${ }^{23}$ the environs of Esztergom/Esztergom (1 piece), ${ }^{24}$ Mány (2 pieces), ${ }^{25}$ Pátka (maybe originally 2 pieces) ${ }^{26}$ Pusztaszabolcs-Felsőcikola (originally 2 pieces), ${ }^{27}$ Százhalombatta/Matrica (1 piece) ${ }^{28}$

16 Kovrig 1937; PATEK 1942.

17 B. Bónis 1975, 248, Fig. 7.2; K. PAlÁgyi - Nagy 2000, 35.

18 Fitz 1957, 142, 146; B. Bónis 1975, 248, Fig. 6; K. PAlÁgyi - NAgy 2000, 38.

19 F. Petres 1965, 90-91, Fig. 26. 3-4, Fig. 33. 2-3.

20 Csontos 1999.

21 Adony/Vetus Salina, 1255/2, salvage excavation (Pongrácz Zsuzsánna, 1994)/Grave No. 2: unpublished, in manuscript: SÁró 2011, Kat. 316, XXXVI. tábla 4. Inv. no.: Intercisa Múzeum 95.19.3. Size: Length: 9.7 cm, Width: $3.8 \mathrm{~cm}$. Description: The fibula is broken. It is made of iron and it has a two-piece construction. It has a pin construction of wires. The bow is plate-like and the sides of the bow are double arched. The bow has probably been covered with a metal-sheet, but this decoration didn't remain. The catchplate is trapezoid and it is not perforated.

22 Budapest/Aquincum, Eastern Cemetery of the Civil Town, Graphisoft Park/Grave No. 795, Inv.no.: Aquincum Museum 2006.5.4739-4740. Budapest/Aquincum Cemetery of the Military Town, Bécsi street 25 - Lajos street 26 - Sajka street 4 (Annamária R. Facsády, 1993-1994)/Grave No. 13: unpublished. Inv.no.: Aquincum Museum 94.6.3760 (2 pcs). 1: Size: Length: $10.8 \mathrm{~cm}$, Width: $4.6 \mathrm{~cm}$. Description: The fibula is broken. The twopiece fibula is made of iron and copper-base alloy. Pin-construction: iron, it consists of wires with internal chord. Bow: made of iron and the sides of the bow are double arched; some remains of the metal-sheet can be seen on the edges, but most of the decoration was destroyed. Rivets can be observed on the bow, above the pin-construction and the catchplate. Catchplate: rectangular, not perforated, and it bends to the right. 2: Size: Length: $11.8 \mathrm{~cm}$, Width: $4.6 \mathrm{~cm}$. Description: The fibula is broken. The two-piece fibula is made of iron and copper-base alloy. Pin-construction: iron, it consists of wires with internal chord. Bow: made of iron and the sides of the bow are double arched; some remains of the metal-sheet can be seen on the edges, but most of the decoration was destroyed. Rivets can be observed on the bow, above the pin-construction and the catchplate. Catchplate: rectangular, not perforated, and it bends to the right. We would like to express our gratitude to Annamária R. Facsády for the research opportunity and Katalin Csontos for her help in the storage.

23 It was found during the excavation of the fort (Zsolt Visy)/stray find. Size: according to K. Csontos: Length: $7.8 \mathrm{~cm}$. Literature: Csontos 1999, 162, Cat. 6, Pl. IV. 3.

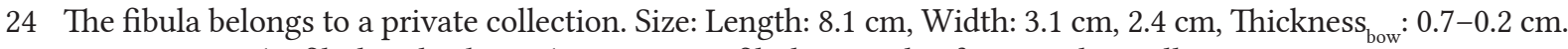
Description: The fibula is broken. The two-piece fibula is made of copper-base alloy. Pin-construction: it consists of $5+3$ wires with internal chord and an axis bar. Wire-hook: it has a narrow, cylindrical shape. Bow: it has a bow-tie shape; its end above the pin-construction is broader than the other; it is decorated with white metal coating on the surface, chased zigzag ornament on the edges and a big, semi-globular umbo in the middle. Catchplate: it is small and rectangular, it bends to the right and is not perforated. I found this fibula with the help of Lajos Juhász, assistant professor of the Eötvös Loránd University Faculty of Humanities, Institute of Archaeological Sciences.

25 Mány, salvage excavation (1959)/Grave No. 5. Size: according to É. F. Petres: the intact piece is $9 \times 3.3 \mathrm{~cm}$ but the size of the broken fibula is unknown (F. Petres 1965, 90-91, Fig. 26. 3-4, Fig. 33. 2-3 = Csontos 1999, 161-162, Cat. 2, Pl. IV. 5).

26 Pátka, tumulus cemetery/Grave No. 56. Size: according to S. K. Palágyi - L. Nagy: approximately $2.85 \times 1.71$ cm (K. Palágyi - Nagy 2000, 35 = Csontos 1999, 162, Cat. 4, Pl. IV. 4).

27 Pusztaszabolcs-Felsőcikola, tumulus cemetery/Grave No. 1. Size: according to S. K. Palágyi - L. Nagy: approximately $10.1 \times 4.2 \mathrm{~cm}$ (K. PALÁGyi - NAGy 2000, 38 = Csontos 1999, 161, Cat. 1, Pl. IV. 2).

28 Százhalombatta, Site 27/28., Olajtározó, Southern Cemetery/Grave No. 107. Size: 10.6×3.4 cm (TopÁL 1981a, 42, 93, Pl. 6.2, Pl. XXXV/Grave 107/11 = TopÁL 1981b, 74 = Csontos 1999, 162, Cat. 5, Pl. IV. 6). 

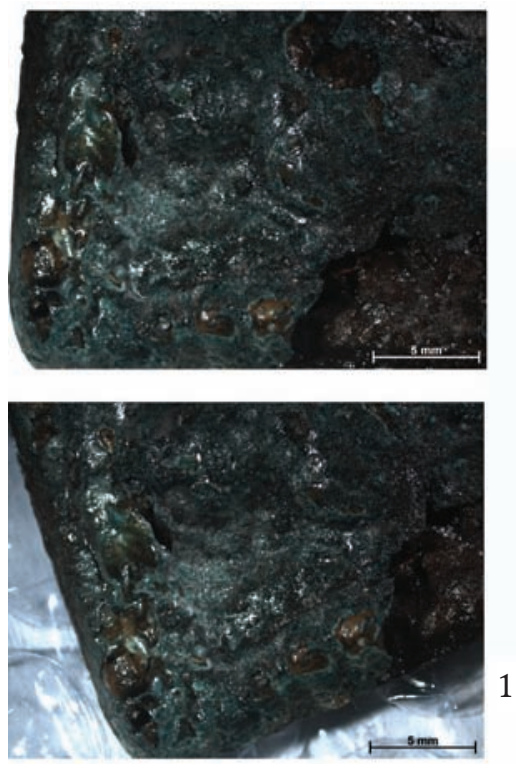
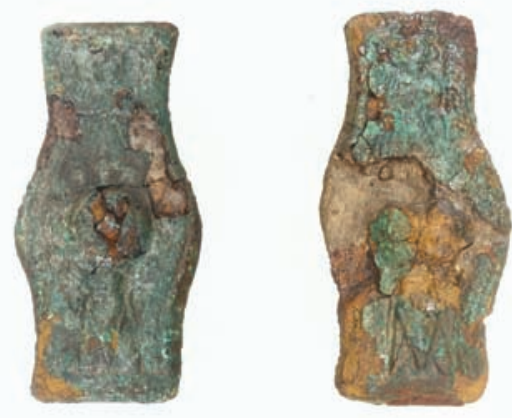

2
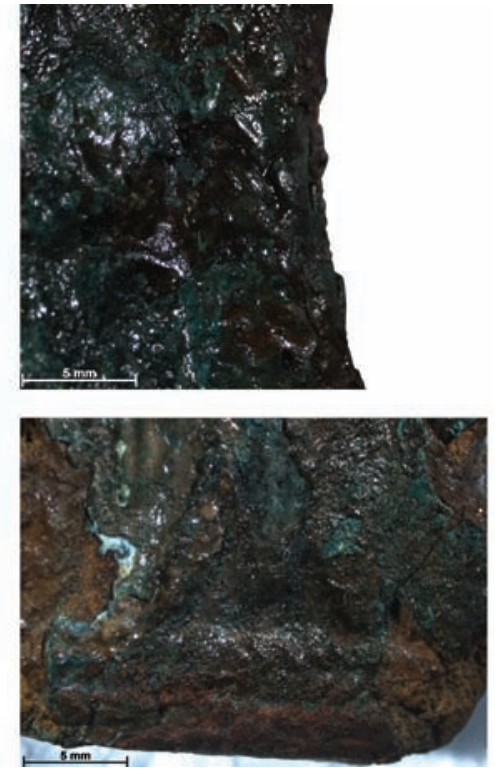

Fig. 8. The edge-ornament on fibulae: $1-$ Nr. 1, 2 - Nr. 2.

the environs of Szekszárd (1 piece) $)^{29}$ and Szőny/Brigetio (originally 2 pieces)..$^{30}$ The number of the known bow-tie shaped fibulae is 17 (Fig. 11-12) and the concentration of these fibulae can be noticed in Northeast-East Pannonia.

Most of the fibulae are known from cemeteries. ${ }^{31}$ Of all the graves, only grave No. 795/Budapest/Aquincum-Graphisoft Park and grave No. 2/Adony/Vetus Salina-MOL gas-station were inhumation burials while the others are cremation burials. Unfortunately, anthropological investigation was only conducted on the human remains from grave No. 795, therefore no information can be shared about the other persons.

In addition to the bow-tie shaped fibulae, there were additional fibulae were in three of the seven graves. Two fibulae are known from grave No. $2 /$ Adony, ${ }^{32}$ four or five fibulae from grave No. 5/Mány ${ }^{33}$ and three fibulae from tumulus No. 56/Pátka. According to the position of fibulae in grave No. 795/Budapest/Aquincum-Graphisoft Park and the depicted fibulae on tombstones, bow-tie shaped fibulae were worn in pairs on the shoulders. This establishment is usually supported by the number of fibulae from graves. ${ }^{34}$ Most of the additional fibulae from grave No. 2/Adony, grave No. 5/Mány and tumulus No. 56/Pátka may have been part of the

29 Stray find. Size: according to K. Csontos: Length: $10 \mathrm{~cm}$ (Csontos 1999, 162, Cat. 7).

30 Stray find. Size: according to K. Csontos: Length: $10 \mathrm{~cm}$ (Csontos 1999, 162, Cat. 3, Pl. IV. 1 = NAGY 2001, Abb. 24. 1).

31 We summarize the knowledge about these burials in the Appendix.

32 In the soil of the grave a further iron object (Inv.no.: Intercisa Museum 95.19.4.) was found. Unfortunately, it is very fragmented and its original shape cannot be reconstructed. We can mot claim undoubtedly that it is a fragment of a cicada fibula.

33 No fragments of an openwork fibula were found in the urn. Based on the available information, it cannot be decided whether the wire fragment belonged to the openwork fibula. Parameters: knee fibula (b): Length: 2.7 cm (F. Petres 1965, 90, 26. ábra 1), wire fragment of a fibula (c): Length: 2 cm (F. Petres 1965, 26. ábra 2), fragments of an openwork fibula (g): in nine pieces (F. Petres 1965, 91).

34 The fibula from grave No. 2/Adony and the fibula from grave No. 107/Százhalombatta are exceptions. It is possible that the pair of the fibula from Adony may have been lost or it has perished. By contrast, we suggest that the fibula from Százhalombatta was put into the grave unpaired on purpose and it can signal a later costume tradition. 

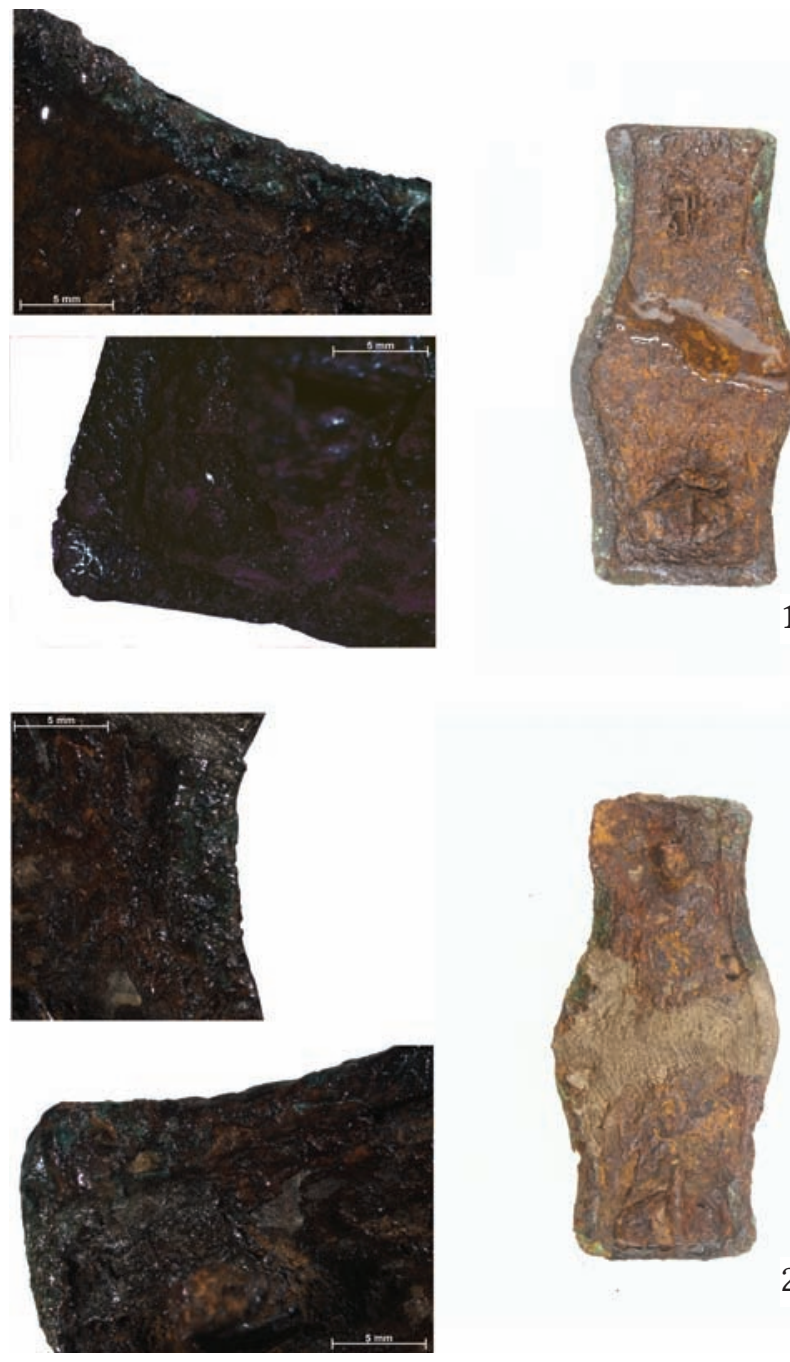

2

Fig. 9. The back of the fibulae: $1-$ Nr. 1, 2 - Nr. 2. deceased's garment. The fibula with looped spring-pin construction ${ }^{35}$ from the grave at Adony was found next to the right arm. It could fix the scarf or the cloak or it could be simply pinned on the cloth. The knee fibula ${ }^{36}$ and the fibula with openwork decoration from the grave at Mány could have belonged to the garment as well. It is possible that two bow-tie shaped fibulae fixed the cloth on the shoulders and other two/three fibulae decorated it under the neckline or on the chest. ${ }^{37}$

Tumulus No. 56/Pátka is more problematic. In this grave three fibulae were found, out of which two are bow-tie shaped fibulae and one is a norico-pannonian winged fibula. Norico-pannonian winged fibulae are known from depictions on tombstones. According to these, norico-pannonian winged fibulae were always worn on the shoulders and they are never found in an additional position. ${ }^{38}$ According to the known grave-contexts, the same statement can be made. Regarding the inhumation burials, norico-pannonian winged fibulae were found on the shoulders or near to collar-bones. ${ }^{39}$ According to all the

35 Wire fibula with plate-like bow. Description: Copper-base alloy. One-piece fibula. Pin-construction: looped wire construction of $4+4$ pieces. Bow: broad, flat, it has a rectangular cross section. The end of the bow is cut off. Catchplate: trapezoidal shape, filled, bends to the right. Length: $5.3 \mathrm{~cm}$, Width: $2.2 \mathrm{~cm}$.

36 Knee fibula (b). Size: Length: 2.7 cm (F. Petres 1965, 90, 26. ábra 1). Type: Berecz 1987, I A-1. A fibula of this type is also known from Baracs/Annamatia, auxiliary vicus (KovÁcs 2005, 114, 118, Fig. 68.4 = SÁRó 2011, Kat. 230).

37 Smaller fibulae could be worn not only on the shoulders but also under the neckline or on the chest. Fibulae of native women's depictions on tombstones show some possible positions. Bow-tie shaped fibulae on their shoulders and a further fibula can be seen depicted on several tombstones from Hungary: CsonTOS 1999, Nr. 19, Pl. I. 1, Pl. VII. 1; Lupa 734, 3586, 3945. Other type fibulae on the depicted women's shoulders and a further fibula can be noticed on some other tombstones from Hungary: Lupa 714, 727, 760, 770, 818, 2779, 2883, 2977, 3180, 3182, 3214, 3445, 3863, 3878, 3945, 3952, 4027, 4041, 4700.

38 We can mention several tombstones from Hungary: Lupa 667, 682, 704-705, 707, 714-715, 717-718, 727-728, $734-735,740,760$ (in both the main picture and the secondary picture), 765, 768, 770, 774, 794, 798-799, $801-803,805,818,830,2697,2779,2838,2851,2853,2854,2859$ (in both the main picture and the secondary picture), 2883, 2973, 2977, 2992, 3059, 3061, 3112, 3129 (in the secondary picture), 3175, 3180-3182, 3185, 3196, 3213, 3214 (in both the main picture and the secondary picture), 3217-3218 (in the secondary picture), 3267 (in both the main picture and the secondary picture), 3273, 3586 (in the secondary picture), 3562, 3578, 3816, 3863, 3883, 3945, 3952, 3974 (in the secondary picture), 3985, 4025, 4027, 4041, 4051, 4700, 5252, 5666, 5984, 7056, 9842, 10176, 10205, 10616 (in the secondary picture), 10631, 10760, 12754, 13137.

39 Examples from the territory of Northeast-Pannonia: grave No. 10/Budaörs (OттомÁnyi 2016, 15, 4. kép, XII. t. 1), grave No. 11/Budaörs (OtтomÁnyi 2016, 15, 4. kép, XVIII. t. 1), grave No. 61/Budaörs (OttománYi 2016, 31, 13. kép), grave No. 93/Budaörs (ОттомÁnyi 2016, 37, 16. kép), grave No. 1/Budapest/Aquincum- 
above-mentioned, the Garbsch A238v norico-pannonian winged-fibula is independent of the deceased person's garment. This fibula could be a gift from a relative or a friend but it also could be a personal object of the deceased. Another option is that tumulus No. 56/Pátka is a double-grave.

Some further jewellery can be mentioned from the graves. A ring with a gemstone may have belonged to the deceased of grave No. 13/Budapest-Sajka street $4 .{ }^{40}$ Further jewellery was found in grave No. 107/Százhalombatta. In this grave, there was a simple, difformed bracelet with round cross-section which has no special characteristics unfortunately.

Ceramic vessels were found in all graves except grave No. 795/Budapest-Graphisoft Park. Among these pieces of pottery not only homemade ware but imports were also found. Terra sigillata can only be mentioned from grave No. 107/Százhalombatta, ${ }^{41}$ but imitations of terra sigillata were found in grave No. 5/Mány and tumulus No. 56/Pátka. ${ }^{42}$ Lamps can also be mentioned. A lamp with stamped CLOR [...] was in grave No. 107/Százhalombatta and a type Loeschke X lamp was in grave 1/Pusztaszabolcs-Felsőcikola. ${ }^{43}$ An imitation of mortarium was found in tumulus No. 56/Pátka. ${ }^{44}$ In addition, several glass vessels can be mentioned from graves No. 13/Budapest-Sajka street 4 and No. 107/Százhalombatta. ${ }^{45}$ The poorest burial is grave No. 2/Adony. In addition to the fibulae, a fragmented iron object and a grey vessel with a heart-shaped profile ${ }^{46}$ were the only other finds in this grave.

Several objects were listed before from the cremation grave No. 13/Budapest-Sajka street 4, the cremation grave No. 5/Mány, the tumulus 56/Pátka, tumulus 1/Pusztaszabolcs-Felsőcikola and the cremation grave No. 107/Százhalombatta. The ring with a gemstone, the terra sigillata vessels, the lamps, the mortarii and their imitations and the glass vessels in these graves testify the roman cultural effect. These deceased lived their life more or less in a Roman way.

Fewer conclusions can be made about the objects from grave No. 2/Adony and grave No. 795/ Budapest/Aquincum-Graphisoft Park. Actually, we can only investigate the grave-goods from grave No. 2/Adony because beside fibulae no other objects came from grave No. 795/Budapest/Aquincum-Graphisoft Park. However, these graves have a great importance because of

Arany-patak street 67 (Budapest History Museum, Archaeology Archives, documentation of the excavation, No. 1821-97), grave No. 176/Budapest/Aquincum-Kaszásdülő-Raktárrét (Zsidi 1984, 96, XXXIX. tábla, 176. sír/2-3), grave No. 18/Budapest/Aquincum-Kecske street 25 and 29 (TopÁl 2003, 77-78, Pl. 84-86, Pl. 119, Pl. 187-189), grave No. 1/Nagyvenyim (B. VÁGó 1960, 46, Abb. 4), grave No. 120a/Páty (Otтományi 2019, 13, 15. tábla), grave No. 137-138/Páty (OtтомÁnyi 2019, 15, 16. tábla), grave No. 162-163/Páty (OtTományi 2019, 15, 18. tábla), grave No. 164/Páty (ОттомÁNyi 2019, 16, 17. tábla, 26. tábla 1), grave No. 248/Páty (ОттомÁnyi 2019, 22, 19. tábla), grave No. 279/Páty (ОттомÁnyi 2019, 26, 24. tábla, 26. tábla 6), grave No. 292/Páty (Оттомányi 2019, 28, 24. tábla), grave No. 302/Páty (Oттомányi 2019, 30, 24. tába, 27. tábla 7), grave No. 1/Sárbogárd-Virágrész (BÁNKI 1998, 65, Abb. 2/Grab 1), grave No. 16/Sárbogárd-Virágrész (BÁNKI 1998, 75, Abb. 4/Grab 16), grave No. 17/Sárbogárd-Virágrész (BÁNKI 1998, 75, Abb. 9/Grab 17), grave No. 21/Sárbogárd-Virágrész (BÁNKi 1998, 75, 79, Abb. 10/Grab 21), grave No. 20/Solymár-Dinnyehegy (V. Kocztur 1991, 177, 16. kép, IV. tábla), grave No. 61/Solymár-Dinnyehegy (V. KoczTur 1991, 184-185, XIV. tábla), grave No. 122/Solymár-Dinnyehegy (V. KoczTur 1991, 198, 83-85. kép, XXXI. tábla), grave No. 145/ Solymár-Dinnye-hegy (V. KoczTur 1991, 202, 95. kép, XXXV. tábla).

40 It is presumably lost.

41 TopÁL 1981a, 85.

42 F. Petres 1965, 91; K. Palágyi - Nagy 2000, 121.

43 Topál 1981a, 42; K. PalÁgyi - Nagy 2000, 131.

44 K. Palágyi - Nagy 2000, 119.

45 TopÁl 1981a, 42.

46 This form belongs to the long-lasting ceramic tradition of the Celts (DELBó 2016, 416). 

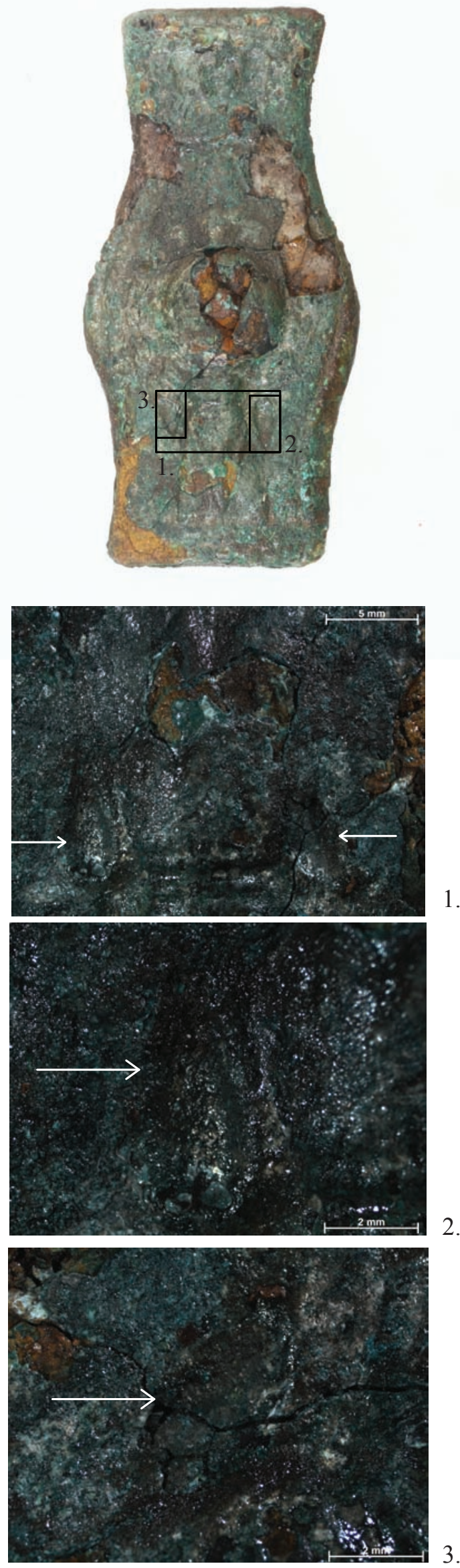

1.

3.
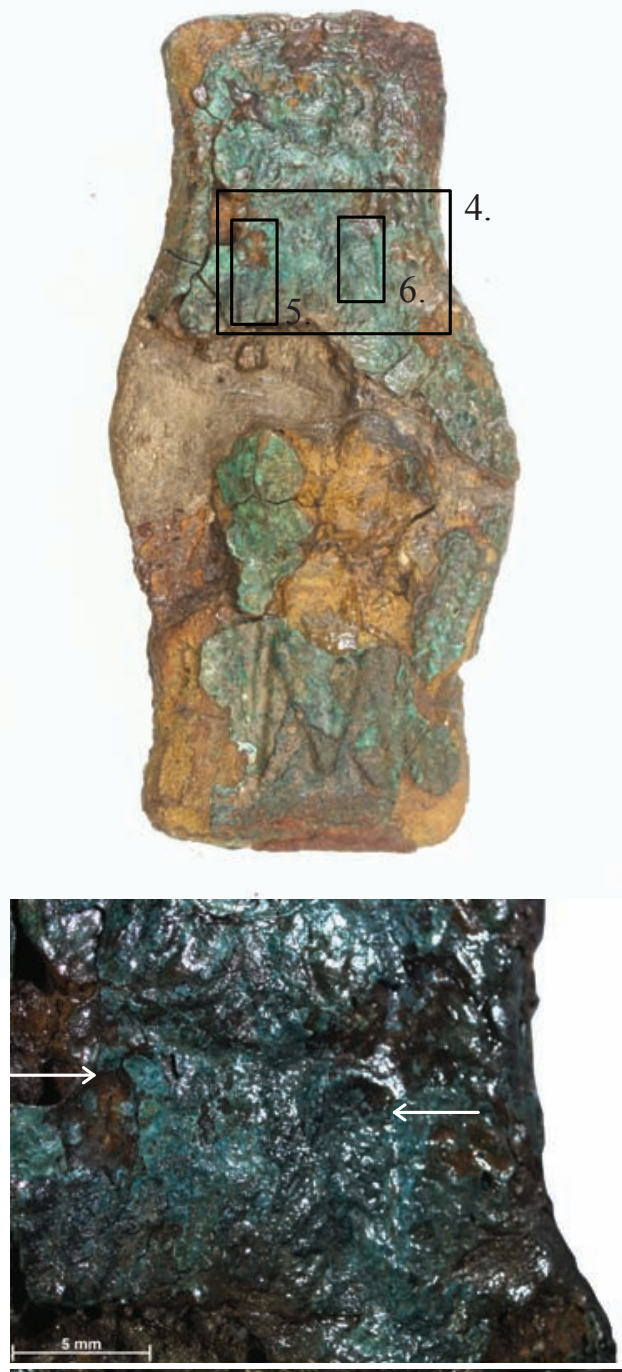

4.
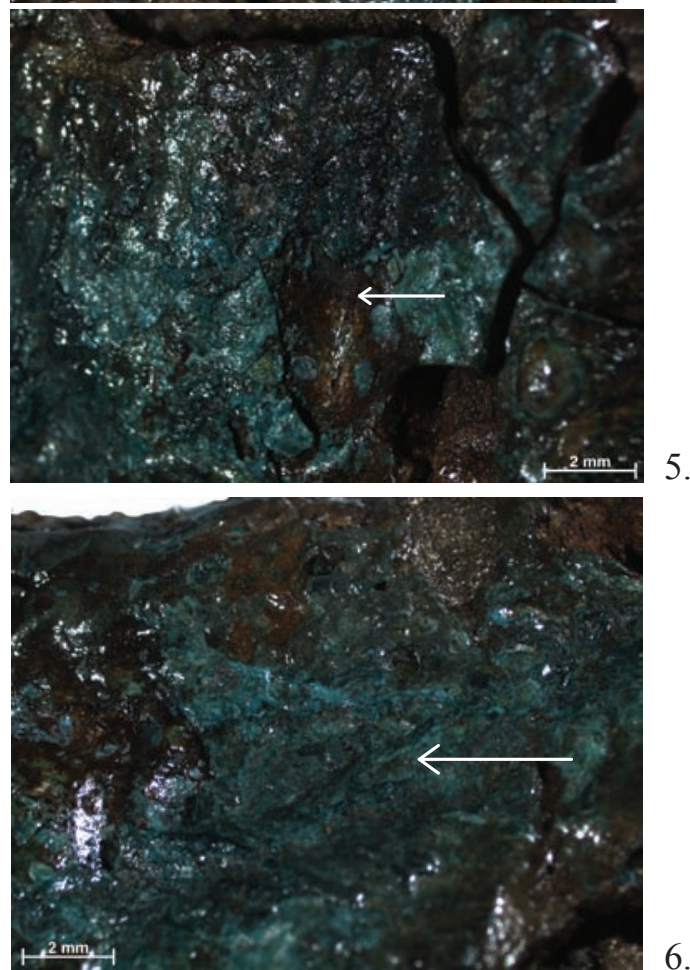

Fig. 10. Drop-shaped fields on the surface: 1-3 - Nr. 1, 4-6 - Nr. 2. 

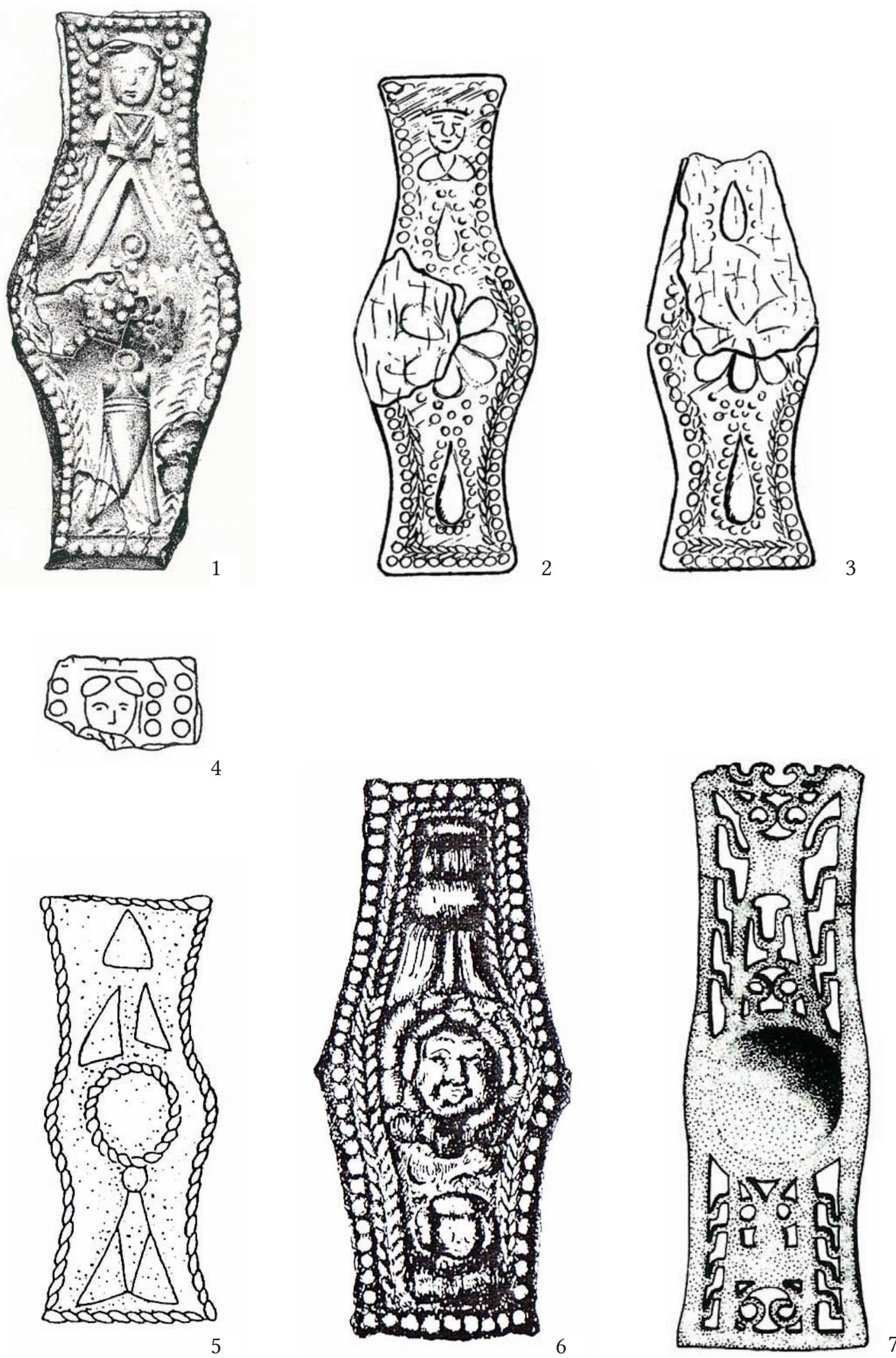

Fig. 11. Bow-tie shaped fibulae from Pannonia: fibulae from the scientific literature. 1 - PusztaszabolcsFelsőcikola/grave no. 1/1 (B. Bónis 1975, 6. kép a), 2 - Mány/grave no. 5/1 (F. Petres 1965, Fig. 26. 3), 3 - Mány/grave no. 5/2 (F. Petres 1965, Fig. 26. 4), 4 - Pátka/grave no. 56 (K. Palágyi - Nagy 2000, Taf. XV. 8), 5 - Dunakömlőd/Lussonium (Csontos 1999, Pl. IV. 3), 6 - Szőny/Brigetio (Csontos 1999, Pl. IV. 1), 7 - Százhalombatta/Matrica/grave no. 107 (TopÁL 1981a, Pl. XXXV/Grave 107/11). 

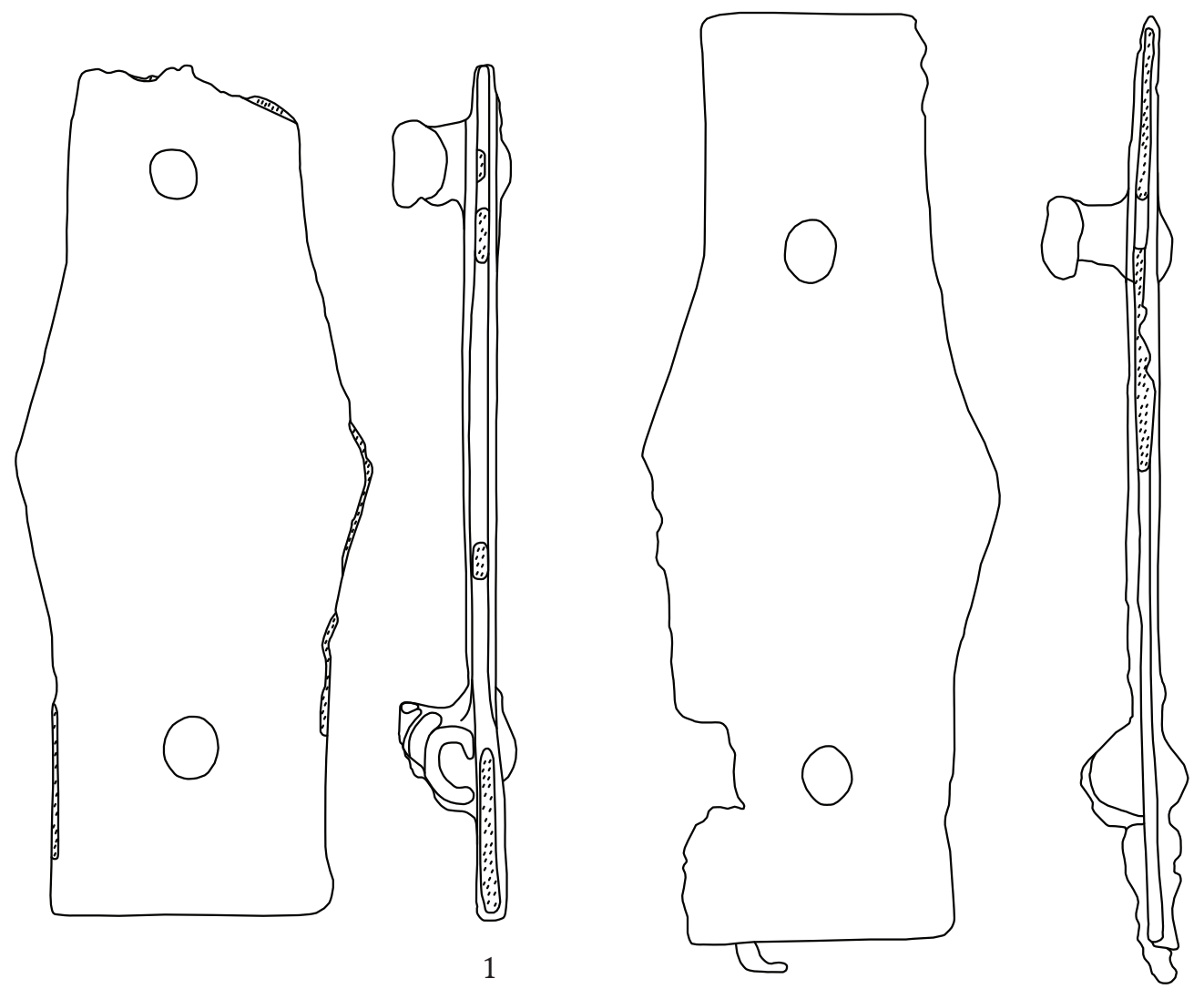

2
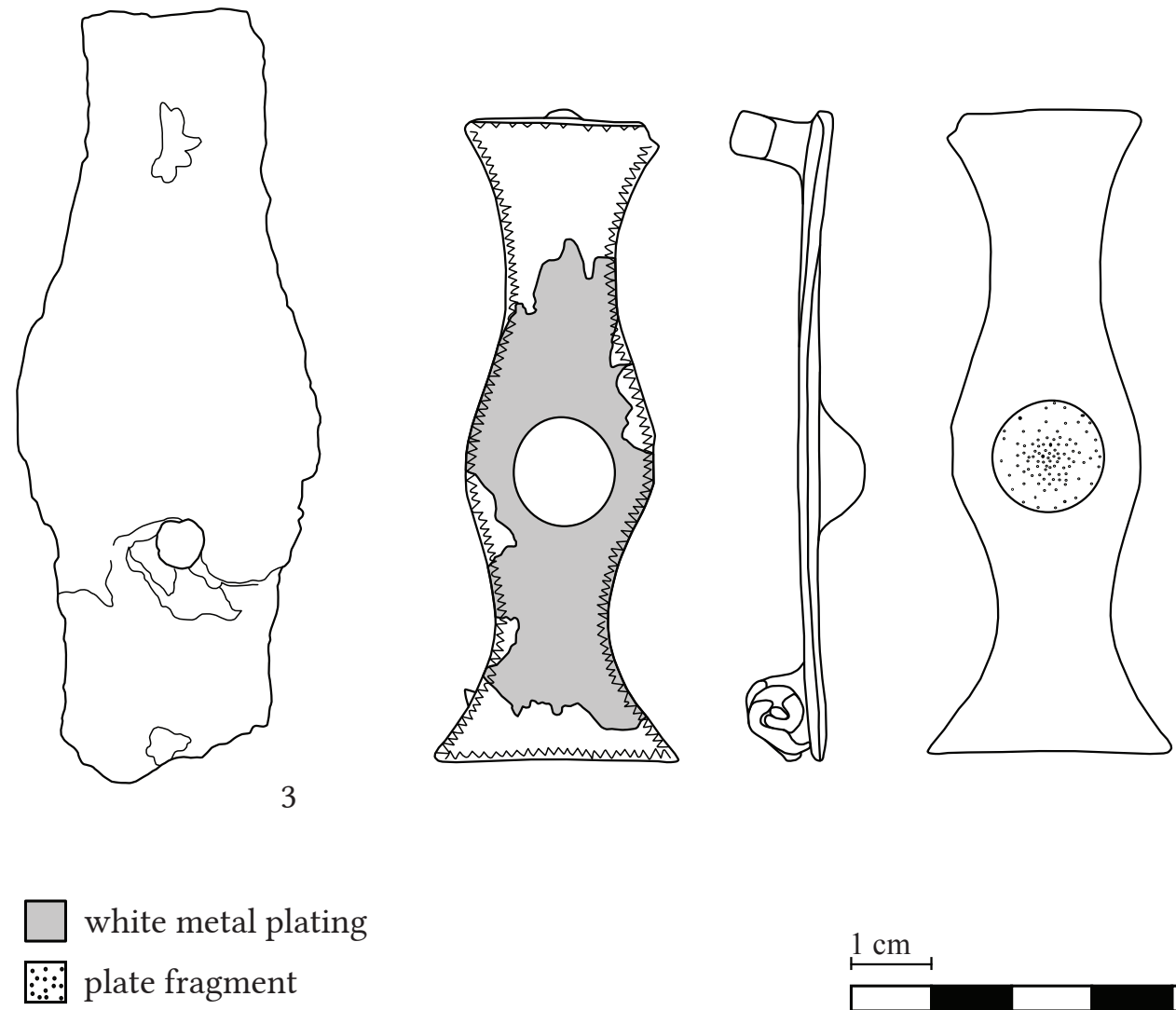

$1 \mathrm{~cm}$

Fig. 12. Newly found bow-tie shaped fibulae from Pannonia. 1 - Budapest-Aquincum-Sajka street 4/ grave no. 13/1, 2 - Budapest-Aquincum-Sajka street 4/grave no. 13/2, 3 - Adony/Vetus Salina/grave no. 2, 4 - Area of Esztergom (all pieces were drawn by Cs. Sáró). 

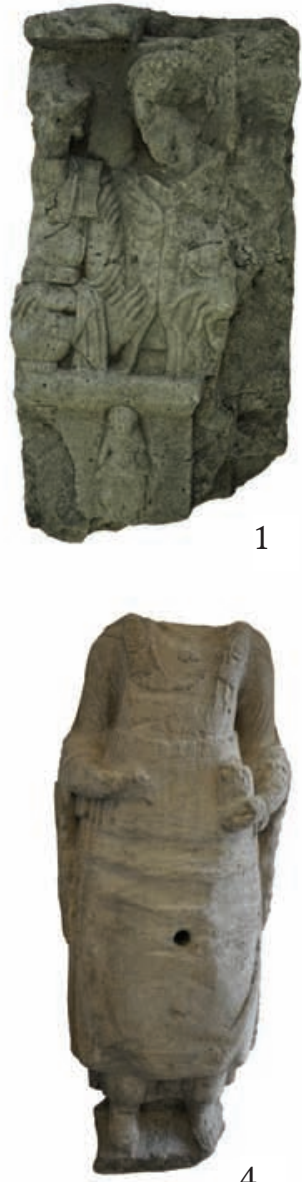
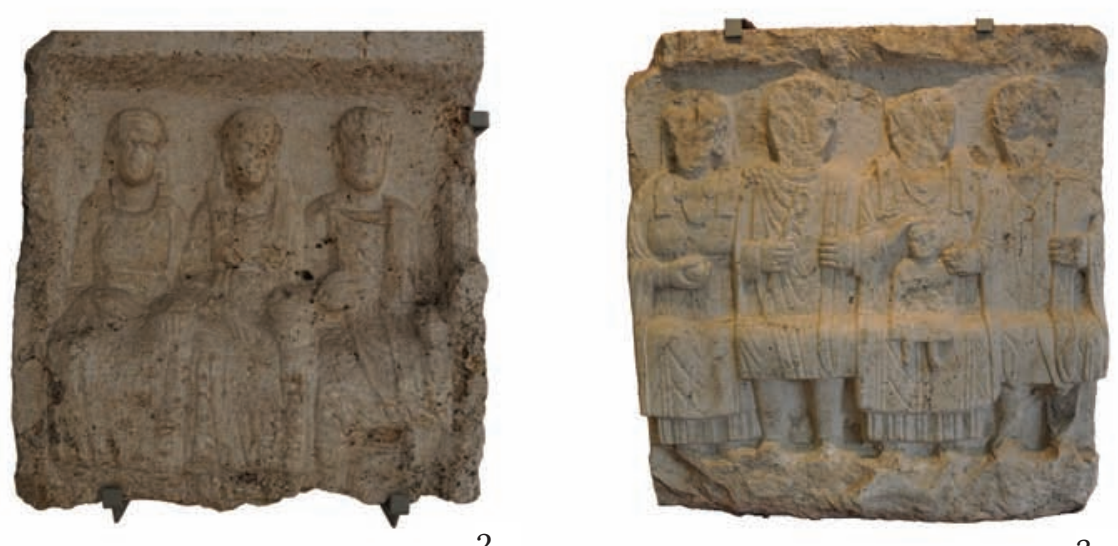

2

3

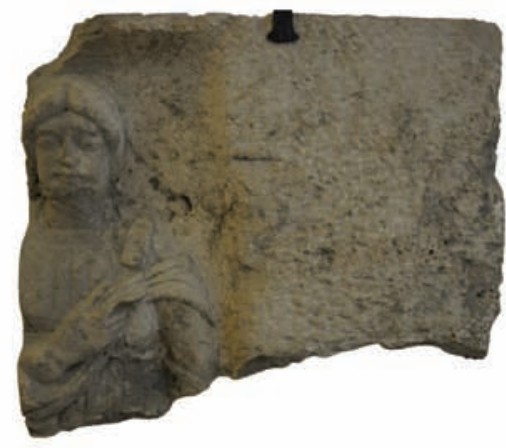

5

6

Fig. 13. Tombstones with the picture of women in native costume and bow-tie shaped fibulae on the shoulders 1: 1 - Dunaújváros/Intercisa, Lupa 39742 - Dunaújváros/Intercisa, Lupa 734, 3 - Dunaújváros/Intercisa, Lupa 3945, 4 - Ercsi, Lupa 726, 5 - Pilisszántó, Lupa 3138, 6 - Lepsény, Lupa 6397. All photos were made by Cs. Sáró.

their ritual. Contrary to the information of nearly 20 years earlier, the people who used bowtie shaped fibulae not only had a cremation but also a skeleton grave ritual. This way of burial was used by the pre-Roman inhabitants of the later province of Pannonia and they changed their practice gradually in the early Roman period. The biritual cemeteries can well present the change of customs. ${ }^{47}$ In grave No. 2/Adony, no import items were found; the grey bowl and the fibula with looped wire pin-construction are local products.

Shortly, we would like to make some statements about the decoration technique of bow-tie shaped fibulae. ${ }^{48}$ The fibulae known so far can be divided into two main groups. The first group includes the fibulae which were supposedly or certainly composed of an inner iron element and a cover of copper-base alloy sheet. Thus the second group includes the fibulae which were made of only one type of metal and which were decorated with a different technique. According to the above, the fibula from grave No. 2/Adony, the fibula from Dunakömlöd/Lussonium,

47 The norico-pannonian winged fibula is a typical type of native habitants. Several graves with this fibula can be mentioned from the cemetery of Solymár-Dinnyehegy. They were also found in inhumation graves No. 20, 61, 122, 145, 155 (V. KoczTur 1991, 177, 184-185, 198, 202, 205) and in cremation graves No. 21, 23, 29, 41, 52, 69, 70, 79, 83, 84, 93, 97, 111, 141 (V. KoczTur 1991, 177-179, 181, 183, 185-189, 191-193, 195, 202).

48 We would like to present our observations about the form, the decoration technique and the patterns of bow-tie shaped fibula in our next study. 
and from Szőny/Brigetio, further the fibulae from grave No. 795/Budapest-Graphisoft Park, grave No. 4/Budapest-Sajka street 13, grave No. 5/Mány, tumulus No. 56/Pátka tumulus No. 1/Pusztaszabolcs-Felsőcikola belong to the first group. Only the fibula from grave No. 107/ Százhalombatta, the fibulae from Esztergom/environs of Esztergom and from the environs of Szekszárd can be classified to the second group.

The decoration of fibulae of the first group is of high quality. The repoussé decoration reveals the high standards and the technical knowledge. These objects are not mass-produced articles but unique and special items.

Decorations can be observed on the fibulae of the second group, however, they are technologically simpler pieces. These fibulae were made of copper-base alloy by casting. The fibula from Százhalombatta and the fibula from the environs of Esztergom were certainly not decorated with embossed metal sheet because other decorations can be observed on their surface. An umbo in relief, white-metal coating and a chased ornament can be seen on the surface of the fibula from the environs of Esztergom. On the fibula from Százhalombatta, the umbo in relief was combined with an openwork decoration. It seems that during the fabrication, these fibulae have been primarily attached to the form typical of the former group and the type of decoration had a secondary role. The mode of decoration may have changed because of the varying technological knowledge of the craftsmen or the different taste of the owner.

\section{Bow-tie shaped fibulae depicted on tombstones}

Same as other fibulae typess, bow-tie shaped fibulae can also be seen on the shoulders of women depicted on tombstones. In her scientific study, K. Csontos has already collected the tombstones from Pannonia ${ }^{49}$ and new pieces could not be added even after our recent research. ${ }^{50}$ Most of these tombstones came from a close area of Pest County and Fejér County from the sites of Dunaújváros/Intercisa, ${ }^{51}$ Ercsi, ${ }^{52}$ Lepsény, ${ }^{53}$ Pilisszántó, ${ }^{54}$ Székesfehérvár ${ }^{55}$ and Tác/Gorsium. ${ }^{56}$ We can mention another tombstone from an unknown site which belongs to

49 Csontos 1999.

50 I collect tombstones with the depiction of women in native costume as part of my PhD study, Hagyományőrzés és romanizáció az eraviscus viselet tükrében - Tradition and Romanization by the dress of the eraviscus tribe (Cs. Sáró).

51 Hungarian National Museum (Budapest) 97.1913.: Csontos 1999, Nr. 11 = Lupa 3974. Inscription: no. Dating: $2^{\text {nd }}$ century (Csontos 1999, 163, Nr. 11), second half of the $2^{\text {nd }}$ century (FITz 1957, 150, Nr. 76); Hungarian National Museum 206.1910.4.: Csontos 1999, Nr. 12 = Lupa 3956. Inscription: no. Dating: second half of the $2^{\text {nd }}$ century (Fitz 1957, 150, Nr. 80; Csontos 1999, 163, Nr. 12); Hungarian National Museum 22.1905.32: Csontos 1999, Nr. 13 = Lupa 734. Inscription: no. Dating: $2^{\text {nd }}$ century (Csontos 1999, 164, Nr. 13), second half of the $2^{\text {nd }}$ century (Fitz 1957, 150, Nr. 79), $2^{\text {nd }}-3^{\text {rd }}$ century (Schober 1923, 130, Nr. 283); Hungarian National Museum 22.1905.31: Csontos 1999, Nr. 14 = Lupa 3945. Inscription: no. Dating: $2^{\text {nd }}$ century (Csontos 1999, 164, Nr. 14), middle of the $2^{\text {nd }}$ century (Fitz 1957, 150, Nr. 78; NAGY 2007, 56, Nr. 49).

52 King St. Stephen Museum (Székesfehérvár) 50.81.1: Csontos 1999, Nr. 17 = Lupa 726. Inscription: no. Dating: $2^{\text {nd }}$ century (Csontos 1999, 164, Nr. 17), second half of the $2^{\text {nd }}$ century (Frtz 1957, 150, Nr. 88).

53 King St. Stephen Museum (Székesfehérvár): Csontos 1999, Nr. 16 = Lupa 6397. Inscription: no. Dating: $2^{\text {nd }}$ century (Csontos 1999, 164, Nr. 16).

54 Hungarian National Museum: Csontos 1999, Nr. 10 = Lupa 3138. Inscription: no. Dating: turning of the $1^{\text {st }}-2^{\text {nd }}$ century (Fitz 1957, 148, Nr. 30), $2^{\text {nd }}$ century (Csontos 1999, 163, Nr. 10).

55 Gorsium. Archaeological Park and Open Air Exhibition (Tác) 10.816: Csontos 1999, Nr. 18. Inscription: no. Dating: $2^{\text {nd }}$ century (Csontos 1999, 165, Nr. 18), the end of the $2^{\text {nd }}$ century (FITz 2003, 95), the beginning of the $3^{\text {rd }}$ century (ERDÉLYi 1974, 40).

56 Gorsium. Archaeological Park and Open Air Exhibition 66.589.1: Csontos 1999, Nr. 15 = Lupa 3586. Its inscription according to HD: D(is) M(anibus) / P(ublius) Ael(ius) Respectus / dec(urio) mun(icipii) v(ivus) f(ecit) 
the Collection of the Aquincum Museum, ${ }^{57}$ and an additional tombstone from Osijek/Mursa (Croatia) (Figs 13-14)..$^{58}$

As mentioned before, bow-tie shaped fibulae are known from a close area, compared to which the South Pannonian tombstone from Osijek/Mursa is an exception. Fortunately, the inscription has remained on this tombstone and it informs us about the customers who ordered this tombstone: it was laid by T(itus) Aur(elius) Avitus, veteran of the legio II Adiutrix for himself and his wife Ulpia Appia. According to the inscription, this tombstone fits to the tombstones from the territory of North-East Pannonia because T(itus) Aur(elius) Avitus has spent more or less time in this area as a soldier in the legio of Aquincum.

On the basis of their form and decoration, several groups can be distinguished among the depicted bow-tie shaped fibulae ${ }^{59}$ Based on their form, we distinguished four types (Fig. 15):

- Pieces belonging to this group are rectangular and they slightly broaden in the middle of their long sides (Lepsény, ${ }^{60}$ Osijek/Mursa, ${ }^{61}$ Pilisszántó,${ }^{62}$ Tác/Gorsium $\left.{ }^{63}\right) .{ }^{64}$

- Pieces belonging to this type have an elongated form. They slightly broaden in the middle of their long side and narrow in the ends (unknown site (AM) ${ }^{65}$ Dunaújváros/ Intercisa ${ }^{66}{ }^{67}$

- Pieces belonging to this type have an elongated form and they are arched in the middle of their long sides (Székesfehérvár $\left.{ }^{68}\right){ }^{69}$

- Pieces belonging to this type have an elongated form and they are arched twice on their long sides (Dunaújváros/Intercisa, $\left.{ }^{70} \mathrm{Ercsi}^{71}\right){ }^{72}$

On the tombstones, further jewellery may join the bow-tie shaped fibulae. Unfortunately, there are no known examples of this in the archaeological material yet. Round pendants were

s(ibi) / et Ulp(iae) Amasiae / coniugi Aelia / Materio fil(ia) / ann(orum) X h(ic) s(ita) e(st) / parentes t(itulum) m(emoriae) p(osuerunt). Dating: $2^{\text {nd }}$ century (GARBsch 1965, 161, Nr. 154.2; Csontos 1999, 164, Nr. 15), the third decade of the $2^{\text {nd }}$ century (FITz 1968, 212, Nr. 56), 124-150 AD (HD017272), 140-180 AD (Lupa 3586).

57 Csontos 1999, Nr. 19. Inscription: - Dating: -.

58 Csontos 1999, Nr. 8. = Lupa 4305. Its inscription according to HD: T(itus) Aur(elius) Avitus / vet(eranus) leg(ionis) II adi(utricis) / ann(orum) LXXVI vivos (!) / sibi et Ulpiae / Appianae con/iugi pientissimae / vivi sibi posue/ru[nt] (HD057374). Dating: 130-170 AD (Lupa 4305), 131-170 AD (HD057374).

59 Six groups of the depicted bow-tie shaped fibulae and the fibulae from archaeological record were made by K. Csontos. The depicted fibulae belong to five of the six groups (Csontos 1999, 158). After our research, the grouping was reconstituted.

60 Lupa 6397.

61 Lupa 4305.

62 Lupa 3138.

63 Lupa 3586. Both women's fibulae belong to this type.

64 These fibulae belong to the fourth group of K. Csontos. She discussed here the fibulae with "elongated hexagonal" form (Csontos 1999, 158).

65 Csontos 1999, Nr. 19.

66 Lupa 3956: the fibulae of the second woman.

67 These fibulae belong to the first and fourth group of K. Csontos. Simple, "undecorated fibulae with double arched sides" belong to her first group and "elongated hexagonal" fibulae were discussed in her fourth group (Csontos 1999, 158).

68 Csontos 1999, Nr. 18.

69 This type matches the third group of K. Csontos (Csontos 1999, 158).

70 Lupa 734: the fibulae of the first woman; Lupa 3945; Lupa 3974.

71 Lupa 726.

72 These fibulae belong to the second and fifth groups of K. Csontos. Decorated fibulae with double arched sides belong to her second group and "propeller-shaped fibulae" were discussed in her fifth group (CsONTOS 1999, 158). 


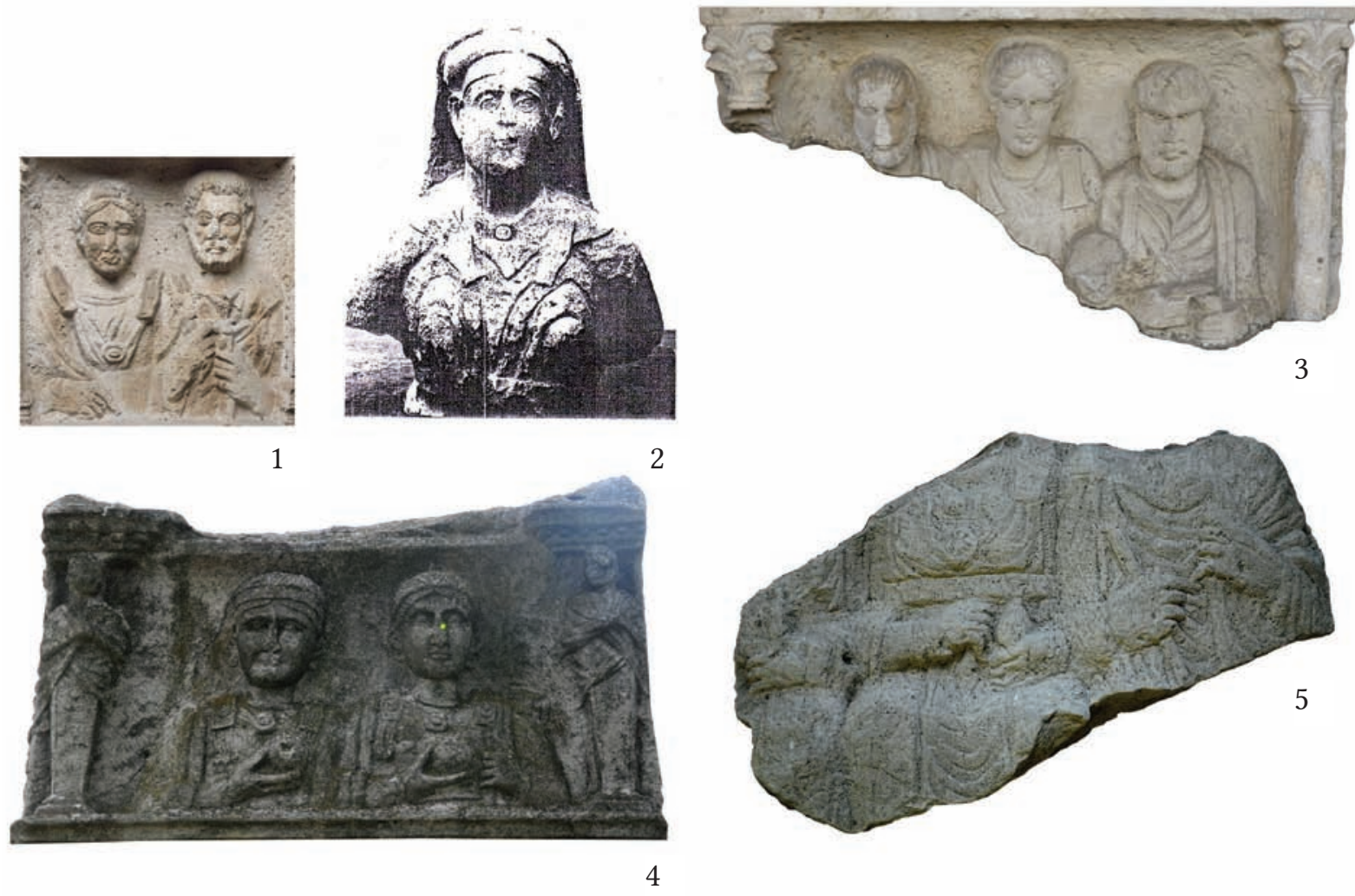

Fig. 14. Tombstones with the picture of women in native costume and bow-tie shaped fibulae on the shoulders 2: 1 - Eszék/Mursa, Lupa 4305 (Lupa), 2 - Unknown site, Aquincum Museum (CsonTOS 1999, Pl. VII. 1), 3 - Székesfehérvár (the photo was made by Cs. Sáró), 4 - Tác/Gorsium, Lupa 3586 (the photo was made by Cs. Sáró), 5- Dunaújváros/Intercisa, Lupa 3956 (the photo was made by Cs. Sáró).

only depicted on one tombstone from Dunaújváros/Intercisa ${ }^{73}$ but heart-shaped or ivy leafshaped pendants can be seen several times: they appear on a tombstone from Dunaújváros/ Intercisa ${ }^{74}$ on a tombstone from Tác $^{75}$ and on a statue from Ercsi. ${ }^{76}$ According to the known images ${ }^{77}$ and the archaeological material, ${ }^{78}$ round pendants and pendants in the shape of an ivy-leaf could complement fibulae of other types as well.

K. Csontos did not mention any tombstones outside of Pannonia with a depiction of bow-tie shape fibulae. During our research, a published tombstone was found in the database of Lupa which should be mentioned here. This broken tombstone with a fragmented figure of a woman and a child was found in Podgradina/Glamoč (Bosnia and Herzegovina). ${ }^{79}$ The adult woman wears a long sleeved dress and she has a round pendant in her neck. On her left shoulder

73 Lupa 734.

74 Lupa 3974.

75 Lupa 3586: on the fibulae of both women.

76 Lupa 726.

77 Round pendants joined to norico-pannonian winged fibulae can be seen on the tombstone from Dunaújváros/Intercisa (Lupa 734, 3578) and Szentendre/Ulcisia (Lupa 705, 760).

78 Some examples can be mentioned. An anchor-shaped fibula with pendants in the shape of an ivy-leaf supposedly came from Brigetio (Popović 1997, 79, Fig. 7). Round pendants joined to norico-pannonian winged fibulae are known from grave No. 10/Budaörs (OtтомÁnyi 2016, 15, 4. kép, XII. t. 1) and grave No. 120a/Páty (OттомÁNyi 2019, 13, 15. tábla).

79 Lupa 30694. Dating: - (Lupa). 
a large-sized, rectangular fibula/bow-tie shaped fibula with decorated surface can be seen, which has a similar shape to the depicted fibulae from Lepsény and Tác. On the underside of the fibula, three cords or chainlets hang and on the first one a pendant in the shape of an ivy-leaf has remained.$^{80}$ The inscription of the tombstone is unknown therefore the connection between the tombstone from Podgradina/Glamoč and the people in Northeast Pannonia is unexplained yet.
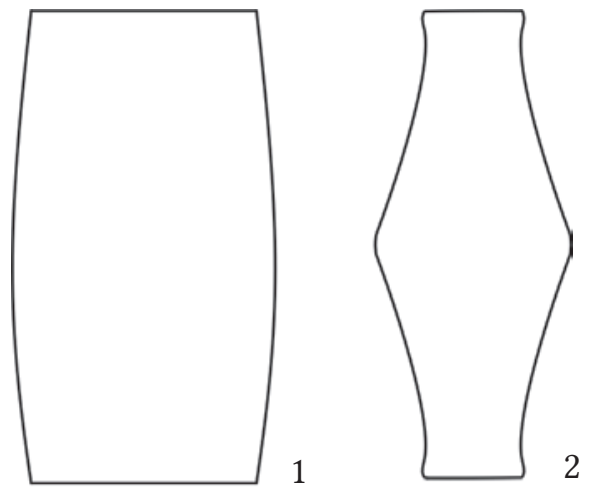

\section{Some questions about the bow-tie shaped fibulae}

During the research concerning bow-tie shaped fibulae, some questions emerged over and over. Namely, where does their form derive from, where were they produced and which native tribe has worn them? The concentration of the fibulae in the territory of Northeast-East Pannonia provided a starting point for the examinations.

J. Fitz wrote a remarkable study about the dress of the eravisci (1957) but he could only discuss the one known pair of fibula from the tumulus 1/Puszta-
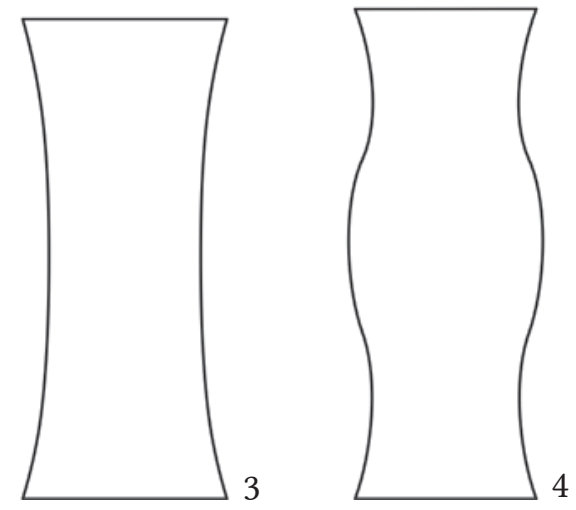

Fig. 15. Forms of the depicted bow-tie shaped fibulae. szabolcs-Felsőcikola. ${ }^{81} \mathrm{~J}$. Fitz supposed the local distribution of the bow-tie shaped fibulae but in his opinion, their original wearers were not the eravisci but other people. This theory is based on the fact that in the territory of the eravisci this type has no antecedent. ${ }^{82}$ According to J. Fitz's opinion, the resettled population is L. Barkóczi's tumulus-cemetery people ${ }^{83}$ who arrived to this territory in the end of the $1^{\text {st }}$ century - at the beginning of the $2^{\text {nd }}$ century AD. According to J. Fitz's investigation, bow-tie shaped fibulae were worn in the $3^{\text {rd }}$ phase of the native dresses and these fibulae were an integral part of the eraviscus dress from around the middle of the $2^{\text {nd }}$ century AD. ${ }^{84}$

When É. F. Petres published the material of the cemetery of Mány (1965), she discussed the questions concerning the bow-tie shaped fibulae in detail. Her examination is based on the bow-tie shaped fibulae from the archaeological material and the depictions. In her investigations, it has an importance that the cemetery of Mány was defined as eraviscus based on its finds and its burial rite. She identified the bow-tie shaped fibulae as a type which was not just

80 In front of the woman, the shape of a girl can be recognized. Her necklace is similar to her mother's, but no pendant is visible. The girl has no fibula on her garment.

81 FITZ 1957, 142.

82 „Lehetséges, hogy ez a fibula-típus amelynek nincs elözménye az eraviszkuszoknál az új lakosság viseletéhez tartozott"(Fitz 1957, 146).

83 BARKóczi 1956, 77-80. The idea was disproved by É. B. Bónis in her study (B. Bónis 1975).

84 Fitz 1957, 141-142: „Mint azonban megállapítottuk, a II. század közepe tájáról származó síremlékeken ezek a fibulák elválaszthatatlanok a tipikus eraviszkusz viselettól. Ebben a körülményben nem annyira a két nép viseletének rokonságát, hanem inkább a halmos temetők néptöredékeinek felszívódását láthatjuk”(FiTz 1957, 146). 
worn by the eravisci but originated from them. ${ }^{85}$ However, the provenance of the eravisci is an important question. At the time of É. F. Petres's study, this tribe was defined as an ethnic group which migrated to Pannonia. ${ }^{86}$

Both É. B. Bónis in her article about the tumulus cemeteries (1975) and É. F. Petres in her study about the problem of the Celtic survival in Pannonia (1990) defined the bow-tie shaped fibulae as a characteristic dress accessory of the eraviscus tribe. ${ }^{87}$ In her study, É. F. Petres identified the eravisci as a Celtic tribe..$^{88}$

K. Csontos has also discussed the origin of the bow-tie shaped fibulae. According to her, their shape comes from the form of the early Roman military belt mountings and their production area was near to the East Pannonian military camps, probably at Tác/Gorsium and its territory. ${ }^{89}$ She connected the high quality of decoration and the claim for this technique with a new, external effect. In her opinion, an eastern connection should be supposed. K. Csontos pointed out that the motifs of fibulae show similarity to the motives of the early Roman glazed pan-handles. ${ }^{90}$

Regarding the origin of the fibula type, further research is necessary. In the framework of this, the technique of metal sheet covering and the known motives of bow-tie shaped fibulae should be examined. Based on our current knowledge some statements can already be made.

As we have pointed out before, a difference of the decoration technique can be seen between the two groups of bow-tie shaped fibulae. Pieces belongingto the first group were decorated with embossed metal sheet, while the others lack this decoration. We believe that a distinction should be made between these groups on the basis of the time and/or site of their production.

The newly published bow-tie shaped fibulae affect our knowledge about the distribution of the type. We currently know of four fibulae from Budapest/Aquincum. In addition, this is the highest number known from the same site. It has a great importance, because Aquincum could not be mentioned before wit cerntainty ${ }^{91}$ and this site should also be regarded in the question of local production.

The wearers of the bow-tie shaped fibulae probably were the members of one or more pre-Roman tribes. If an inscription had mentioned the ethnicity of a deceased person while depicting bow-tie-shaped fibulae, that would be factual information. Unfortunately, just a few examples are known and in these cases women wear fibulae of other types. ${ }^{92}$

85 F. Petres 1965, 98.

86 F. Petres 1965, 100.

87 B. Bónis 1975, 248; F. Petres 1990, 13.

88 F. Petres 1990, 10-13.

89 Csontos 1999, 159-161.

90 Csontos 1999, 161. This research was continued by L. Nagy (Nagy 2001, 140-150).

91 The fragment of the funerary statue (Csontos 1999, 165, Nr. 19, Pl. I. 1, Pl. VII. 1) is known only from a photograph and its find place is problematic. It could not only come from Budapest/Aquincum but also from Szentendre/Ulcisia or other surrounding areas.

92 The woman wears pre-Roman garment and norico-pannonian winged fibulae on her shoulders: Lupa 805.: Site: Tác/Gorsium. Its inscription according to HD: Flavia Tattunis / filia Usaiu Eravi/sca annor(um) LXXX / hic sita est / Q(uintus) Flavius Titucus matri ob pietatem posuit (HD009655). The woman wears pre-Roman garment and fibulae (possibly norico-pannonian winged fibulae) on her shoulders: Lupa 716: Site: Sárisáp. Its inscription according to HD: Aicca Cansali f(ilia) / Asalia an(n)oru/m XL Racio uxo/ri\{s\} suae titulum / pos(u)it (HD038309). The woman wears pre-Roman garment and fibulae (definitely not norico-pannonian winged fibulae) on her shoulders: Lupa 76: Bruckneudorf/Királyhida. Its inscription according to HD: Belatusa Cau/ti l(iberta) Boius pos/uit an(n)oru(m) XXX / XXX / hic sita / est (HD028222). 
We have to be careful to make a conclusion based on the distribution area of the bow-tie shaped fibulae. Fibulae of this type may be preserved in bad condition, probably a fragment of the inner iron element and they cannot be easily recognized in the excavation or at the storage of a museum. Due to the high quality decoration, the prestige of these objects and also the vulnerable construction, the number of the known bow-tie shaped fibulae is low. Therefore some newly recognized bow-tie shaped fibulae can easily modify our knowledge about the distribution area. Here we should mention again the fibulae from Aquincum and the fibula depiction from Podgradina/Glamoč. The former site drives us to more questions.

\section{Summary}

Thanks to the fibulae from the cemetery of Budapest/Aquincum-Graphisoft Park/grave No. 795, the bow-tie shaped fibula type can be discussed anew. Since the study of K. Csontos (1999), further bow-tie shaped fibulae were found and could be presented here. The information regarding the previously known fibulae was also collected and summarized.

In the present study, our aim was to present the newly found examples, update their number and discuss their find circumstances where possible. After this work new or unsolved questions arise. Were these fibulae produced in the province or are they imports? If they were produced here where should we localize the center of their production? If we accept that they had a long term use, what kind of thought should be supposed behind this? Can we truly assign this type to one pre-Roman tribe? Could these fibulae belong to one or more family/ clan with a special status? How can their presence as part of the depicted women's garment be explained? Does it have any chronological importance or not?

As we mentioned before, this type of fibula will be the subject of our further investigations. Firstly, we would like to examine the decoration technique, the embossed metal sheet covering on other types of fibulae and further dress accessories. Moreover, we would like to study the motives of bow-tie shaped fibulae in detail.

\section{References}

BARKóczi, L. 1956: Császárkori kelta edényégető telep Bicsérden. Folia Archaeologica 8, 63-87.

BÁNKI, Zs. 1998: Kelten- und Eraviskergräber in Sárbogárd. Communicationes Archaeologicae Hungariae, 65-98.

Berecz, K. 1987: Adatok a térdfibulák Pannoniai történetéhez. Unpublished MA-thesis. Budapest.

Bíró, M. 2003: Ein neuerer Beitrag zur pannonischen einheimischen Frauentracht. In: SzABó, Á Tóth, E. (Hrsg.): Pannonica provincialia et archaeologia. Studia Sollemnia E. Fitz octogenario dedicate. Libelli Archaeologici Ser. Nov. No. I. Budapest, 89-102.

B. BóNIs, É. 1975: A noricumi-pannóniai halomsíros temetkezés korhatározásának kérdése. A Fejér megyei tumulusok jellegzetes emlékanyaga (Die Datierungsfrage der norisch-pannonischen Hügelgräber. Einige charakteristischen Gegenstände aus den ost-pannonischen Tumuli). Archaeologiai Értesító 102, 244-249.

BugÁN, A. 2000: Az Aquincumi Múzeum kisebb leletmentései és szondázó jellegű feltárásai az 1999. évben. Budapest, III. ker., Graphisoft Park (volt Gázgyár) (Hrsz. 19333). Aquincumi Füzetek 6, 111.

Csontos, K. 1999: Pannonian Plated Fibulas. Antaeus 24, 157-168.

DeLbó, G. 2016: A budaörsi temető kora római kerámiaanyaga. In: OtтомÁnYI, K. (ed.): A budaörsi római vicus temetője. Budapest, 396-431. 
ERDÉLyi, G. 1974: A római kőfaragás és kőszobrászat Magyarországon. Apollo Könyvtár 5. Budapest.

ERdÉlyi, G. - Fülep, F. 1954: Kőemlék-katalógus. In: R. Alföldi, M. - BARKóczi, L. - ERdÉLyi, G. FERENCZy, E. - FÜLEP, F. - NemESKÉRI, J. - SÁGI, K.: Intercisa (Dunapentele-Sztálinváros) története a római korban I. Archaeologia Hungarica 23. Budapest, 233-276.

FITZ, J. 1957: Az eraviszkusz női viselet (Die Tracht der Eraviskennen). Archaeologiai Értesítő 84, 133-154. Fitz, J. 1968: Römische Inschriften im Komitat Fejér. Alba Regia 8-9, 197-214.

Fitz, J. 2003: Gorsium - Herculia. Székesfehérvár.

Gabler, D. - Hárshegyi, P. - Lassányi, G. - VÁmos, P. 2009: Eastern mediterranean import and its influence on local pottery in Aquincum. Acta Archaeologica Academiae Scientiarum Hungaricae $60,51-72$.

GARBSCH, J. 1965: Die norisch-pannonische Frauentracht im 1. und 2. Jahrhundert. Münchener Beiträge zur Vor- und Frühgeschichte 11. München.

V. KoczTur, É. 1991: Kora császárkori temető Solymáron (Frühkaiserzeitliches Gräberfeld in Solymár). Studia Comitatensia 22, 171-334.

KovÁcs, P. 2005: Excavations in the roman auxiliary fort of Annamatia (Baracs) between 1999 and 2005. Budapest.

Kovrig, I. 1937: A császárkori fibulák fó formái Pannoniában. Die Haupttypen der kaiserzeitlichen Fibeln in Pannonien. Dissertationes Pannonicae II/4. Budapest.

Kuzsinszky, B. 1892: Római kori temető Aquincumban. Archaeologiai Értesítő 12, 446-448.

LassáNYI, G. 2005: Az Aquincumi Múzeum kisebb feltárásainak helyszínei és eredményei a 2004. évben/19. Budapest, III. ker., Záhony utca 7. (Hrsz.: 19343/6, 19332/2). Aquincumi Füzetek 11, $228-230$.

LASSÁNYI, G. 2006: Római temető és gazdasági épületek feltárása a volt Gázgyár (ma Graphisoft Park) területén (Excavation of a Roman cemetery and out-buildings in the territory of the former Gas Factory (today known as Graphisoft Park)). Aquincumi Füzetek 12, 30-36.

LASSÁNYI, G. 2007: Előzetes jelentés az aquincumi polgárváros keleti (gázgyári) temetőjének feltárásáról (Preliminary report of the excavation in the eastern cemetery (Gas Factory) of the Aquincum Civil Town). Aquincumi Füzetek 13, 102-116.

LASSÁNYI, G. 2008: Előzetes jelentés az aquincumi polgárváros keleti (gázgyári) temetőjében 2007-ben végzett feltárásokról (Preliminary report of the excavation in the eastern cemetery (Gas Factory) of the Aquincum Civil Town). Aquincumi Füzetek 14, 64-70.

LASSÁNYI, G. 2010: Feltárások az egykori Óbudai Gázgyár területén (Excavations in the area of the former Óbuda Gas Factory). Aquincumi Füzetek 16, 25-38.

LAsSÁNYI, G. 2011: Kora bronzkori és római kori temetőrészlet feltárása a volt Óbudai Gázgyár déli részén (Excavation of parts of Early Bronze Age and Roman cemeteries in the southern part of the former Óbuda Gas Factory). Aquincumi Füzetek 17, 36-51.

LAssányi, G. 2016: A Budapesti Történeti Múzeum kisebb feltárásainak helyszínei és eredményei a 2015. évben. Budapest III. ker., Záhony u. 7. (hrsz.: 19333/46). Aquincumi Füzetek 22, 146-149.

LAssÁNYI, G. 2017: A városlakók végső nyughelye: a polgárvárosi nekropoliszok. In: ZsıDI, P. (ed.): Kincsek a város alatt. Ujdonságok a múltból. Budapest régészeti örökségének feltárása. 1867/20052015. Kiállitási vezetó és katalógus. Budapest, 78.

LASSÁNYI, G. - SzEREDI, A. 2017: Ásatások a Graphisoft Park Déli részén (Excavation of parts of Early Bronze Age and Roman cemeteries in the southern part of the former Óbuda Gas Factory). Aquincumi Füzetek 23, 81-88.

LassánYi, G. - VÁmos, P. 2011: Two North African red slip jugs from Aquincum. Acta Archaeologica Academiae Scientiarum Hungaricae 62, 147-161.

LASSÁNYI, G. - VASS, L. 2015: Az „utolsó” rómaiak - adatok Aquincum polgárvárosának kései történetéhez egy agancsfésű kapcsán. Budapest Régiségei 48, 169-187. 
Nagy, L. 2001: Römerzeitliche Hügelgräber in Pusztaszabolcs-Felsőcikola. Communicationes Archaeologicae Hungariae, 125-160.

Nagy, M. 2007: A Magyar Nemzeti Múzeum régészeti kiállitásának vezetője. Római Kötár. Lapidárium. Budapest.

OтtomÁnyi, K. 2016: A budaörsi római vicus temetője. In: OtтомÁnYI, K. (ed.): A budaörsi római vicus temetóje. Budapest, 9-372.

OTtomÁnyi, K. 2019: A pátyi temető római sírjai (Malom-dűlő). Szentendre.

K. Palágyi, S. - Nagy, L. 2000: Római kori halomsírok a Dunántúlon. Veszprém.

PATEK, E. 1942: A pannoniai fibulatípusok elterjedése és eredete. Verbreitung und Herkunft der römischen Fibeltypen in Pannonien. Dissertationes Pannonicae II/19. Budapest.

F. Petres, É. 1965: A mányi eraviscus temető (Das eraviskische Gräberfeld von Mány). Folia Archaeologica $17,87-102$.

F. Petres, É. 1990: The problem of the celtic survival in Pannonia. Alba Regia 24, 7-15.

Popović, I. 1997: Miscellanea Argentea. Starinar 48, 73-90.

Rothe, U. 2012: Clothing in the Middle Danube provinces. The garments, their origins and their distribution. Fahreshefte des Österreichischen Archäologischen Instituts 81, 137-231.

Rothe, U. 2013: Die norisch-pannonische Tracht - gab es sie wirklich? In: GrabHerr, G. - KaInRATH, B. SCHIERL, T. (eds): Relations Abroad. Brooches and other elements of dress as sources for reconstructing interregional movement and group boundaries from the Punic Wars to the decline of the Western Roman Empire. Proceeding of the International Conference from 27th-29th April 2011 in Innsbruck. IKARUS. Band 8. Innsbruck, 34-48.

SÁRÓ, Cs. 2011: A pannoniai közép-dunai limes kora császárkori fibulatípusai. Unpublished MA-thesis. Budapest.

SÁRó, Cs. 2018: Roman fibulae as part of women's costume: examination of tombstones from Komárom-Esztergom County. In: Borhy, L. - DévaI, K. - Tankó, K. (eds): Celto - Gallo - Roman. Studies of the MTA-ELTE Research Group for Interdisciplinary Archaeology. Paris, 259-279.

SchoBer, A. 1923: Die römischen Grabsteine von Noricum und Pannonien. Sonderschriften des Österreichischen Archäologischen Institutes in Wien 10. Wien.

TopÁL, J. 1981a: The southern cemetery of Matrica (Százhalombatta-Dunafüred). Fontes Archaeologici Hungariae, Budapest.

TopÁL, J. 1981b: Matrica (Százhalombatta-Dunafüred) korai- és középső-császárkori temetője (Das früh-und mittelkaiserzeitliche Gräberfeld von Matrica (Százhalombatta-Dunafüred)). Archaeologiai Értesitón 108, 70-78.

TopÁL, J. 2003: Roman cemeteries of Aquincum, Pannonia. The western Cemetery (Bécsi Road) II. Budapest.

B. VÁGÓ, E. 1960: Kelten- und Eraviskengräber von Nagyvenyim und Sárkeszi. Alba Regia 1, 43-62.

VÁmos, P. - LAssÁnYi, G. 2010: Észak-afrikai korsók Aquincumban. Ókor 9/4, 61-65.

Zsıdi, P. 1984: A Kaszásdúló - raktárréti római kori temető elemzése. Unpublished MA-thesis. Budapest.

Zsıdi, P. 1997: Szondázó jellegű feltárás az aquincumi polgárvárostól délkeletre (Test excavations carried out southeast of the Aquincum Civil Town). Aquincumi Füzetek 3, 54-57.

Zsıdi, P. 1999: A római kori partépítés nyomai a Duna polgárvárosi szakaszán (Research along the Danube Bank near the Aquincum Civil Town). Aquincumi Füzetek 5, 84-94.

ZsıDI, P. 2001: Kutatások az aquincumi polgárvárostól keletre lévő területen (Research in the territory east of the Aquincum Civil Town). Aquincumi Füzetek 7, 76-84.

Zsidi, P. - REMÉNYI, L. 2003: Duna-parti út részlete és őskori maradványok a polgárvárostól délre (Detail from the road on the Danube bank and prehistoric remains south of the Civil Town). Aquincumi Füzetek 9, 86-94. 


\section{Online sources}

HD = https://edh-www.adw.uni-heidelberg.de/home?lang=de

Lupa = F. HARL - O. HARL: Bilddatenbank zu antiken Steindenkmälern. (www.ubi-erat-lupa.org)

\section{Appendix}

Adony/Vetus Salina, 1255/2, MOL gas station

Grave No.: 2

Ritual: inhumation, simple pit with extended skeleton

Sex and age of the deceased: ?/?

Number of the bow-tie shaped fibulae: 1

Further costume accessories: 1 bowfibula with looped spring-pin construction (IM 95.19.2.)

Further grave-goods: 1 fragmentary iron object (IM 95.19.4.); pottery: 1 grey bowl with heart-shaped profile and horizontal flutes under the rim (IM 95.19.1.)

Literature: -

\section{Budapest/Aquincum-Graphisoft Park}

Grave No.: 795

Ritual: inhumation, double, simple pit with extended skeletons

Sex and age of the deceased: woman (25-29) + child (3-4)

Number of the bow-tie shaped fibulae: 2

Further costume accessories: no

Further grave-goods: no

Literature: -

Budapest/Aquincum-Lajos street 26 - Sajka street 4.

Grave No.: 13

Ritual: cremation, pseudo-urn grave, the remins were probably put into a box/casket

Sex and age of the deceased: ?/?

Number of the bow-tie shaped fibulae: 2

Further costume accessories: 1 cracked, undecorated ringstone (missing)

Further grave-goods: fragments of a bronze vessel (?); fragments of bronze umbos; 1 scent-glass; pottery: 1 vessel, 2 ceramic jugs

Literature: -

\section{Mány}

Grave No.: 5

Ritual: cremation, urnburial

Sex and age of the deceased: ?/?

Number of the bow-tie shaped fibulae: 2

Further costume accessories: knee fibula, BERECZ 1987, I A-1 (b); fragment of a spring-pin contsuction (c); fragments of an openwork fibula (g)

Further grave-goods: iron nails (19 pcs.) (e); fragments of an iron sheet (9 pcs.) (f); stone; pottery: 1 urn, 
B. Bónis XI.3 (a); 1 urn (i); 1 bowl, imitate a terra sigillata form (h); 1 low bowl (j)

Literature: F. Petres 1965, 90-92, 25. ábra 1-2, 26. ábra 1-4, 27. ábra 1-2, 30. ábra 2-4, 31. ábra 1, 3, 33. ábra $2-3$.

\section{Pátka}

Grave No.: 56

Ritual: cremation, tumulus

Sex and age of the deceased: ?/?

Number of the bow-tie shaped fibulae: 2 ?

Further costume accessories: norico-pannonian winged fibula, Garbsch A238v

Further grave-goods: pottery: 1 flagon without neck and handle; 1 little cup, imitation of Drag. 33 terra sigillata (acetabulum); 1 imitaion of a mortarium; further pottery fragments

Literature: K. PALÁgYi - NAGY 2000, 35, 119, 121.

\section{Pusztaszabolcs-Felőcikola}

Grave No.: 1

Ritual: cremation, tumulus

Sex and age of the deceased: ?/?

Number of the bow-tie shaped fibulae: 2 ?

Further costume accessories: no

Further grave-goods: pottery: 1 lamp, Loeschke X; 2 one-handled flagons; 1 grey bowl, Pernička 4B; 1 lid; 1 pot; 1 grey bowl; further pottery fragments

Literature: K. PALÁgyi - NAgy 2000, 38-39, 115-116, 125, 131, 255, 3. kép; NAGY 2001, 125-128.

\section{Százhalombatta/ Matrica, southern cemetery}

Grave No.: 107

Ritual: cremation

Sex and age of the deceased: ?/?

Number of the bow-tie shaped fibulae: 1

Further costume accessories: bronze bracelet (12)

Further grave-goods: glass vessels: fragments of a light green balsamarium (9); fragemts of a white glass vessel (10); pottery: lamp with a stamp CLOR [...] (8); Drag. 18/31 terra sigillata bowl with a stamp CARANTINIM, a cross, a star and a graffito M/... (3) Workshop: Mid Gaul, Lezoux, Carantinus; 1 flagon (1), 1 two-handled flagon (7); fragments of 1 three-legged bowl (5); 1 bowl (2); 1 jar (4); 1 base fragment of a jar (6)

Literature: TopÁL 1981a, 41-42, 85, Pl. 35. Grave 107. 